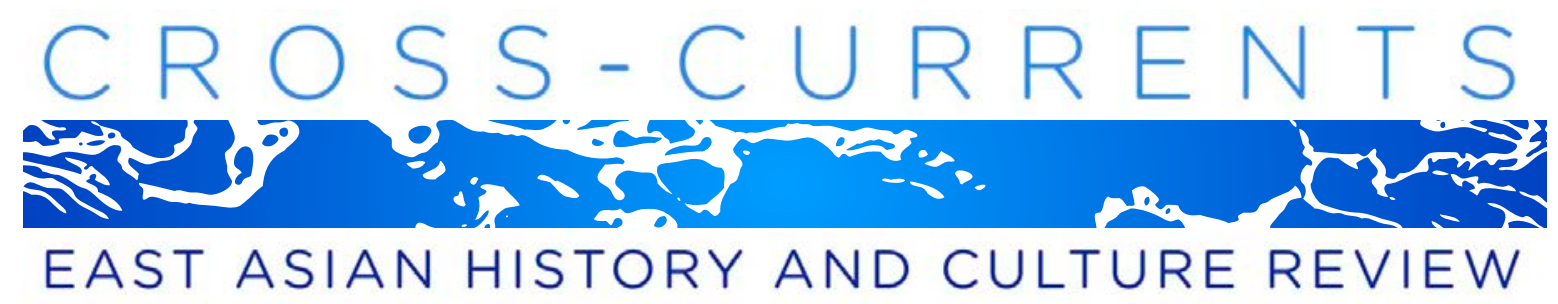

\title{
France and the Gulf of Tonkin Region: Shipping Markets and Political Interventions in South China in the 1890s
}

Bert Becker, University of Hong Kong

\begin{abstract}
In the period of "new" imperialism in the late nineteenth and early twentieth centuries, France strived to create a sphere of influence in southwest China. To foster such imperialist policies, France's policy makers regarded French companies operating in East Asia as instrumental. One such firm was Auguste Raphael Marty's Tonkin Shipping Company, based in Haiphong, French Indochina, which operated steam coasters across the wider Gulf of Tonkin region. In the region's highly competitive shipping market, Marty strived to achieve a monopoly when favorable conditions permitted during the final phase of the Sino-Japanese War. His profit-driven strategy caused huge losses for Chinese shippers and ultimately resulted in their boycotting his ships through the Tsap Yet syndicate. When French officials intervened on Marty's behalf in negotiations with the Chinese government, the Syndicate was finally dissolved. It was followed by an agreement between the Chinese firm of Yuen Cheong Lee and Co. and the German firm of Jebsen and Co., based on long-established mutual trust between the owners. Although Marty received monetary compensation for his losses, he ruined his relationship with Chinese merchants. This case study presents little-known facts about the interactions among foreign firms in China and demonstrates the Chinese ability to react efficiently to unfair business practices.
\end{abstract}

Keywords: French imperialism, Chinese shipping business, southwest China, Gulf of Tonkin, Hoihow, Pakhoi, Haiphong, Western tramp shipping, Tonkin Shipping Company, Marty et d'Abbadie, Auguste Raphael Marty, Yuen Cheong Lee and Co., Jebsen and Co., Schomburg and Co., Tsap Yet Syndicate, Sir Robert Hart, Edmund Baron von Heyking, Kwang-chow-wan, Kiaochow

\section{Introduction}

Business formed an integral part of European imperialism, and "money-making was part of the imperial impulse" (Aldrich and McKenzie 2014, 4). In the period of "new" imperialism during the late nineteenth and early twentieth centuries (in contrast to Western imperialism in the early 
modern period), the global expansion of Western businesses into Asia resulted in increased rivalries between steamship companies that each sought to gain a share in the lucrative freight markets. While European liner shipping companies predominantly operated intercontinental routes, European tramp shipping companies in China found their major markets in coastal, riverine (or cabotage), and interregional shipping in East Asia. The economic and business dimension of such competition was further propelled by the imperialist-colonialist ambitions of European powers in China and Asia, which reached their climax around 1900.

Among the imperialist powers, France engaged in a new expansionist policy in East Asia starting in the 1880s. The scene was set with France's earlier military involvement in the First and Second Opium Wars (1839-1842 and 1856-1860, respectively), the opening of the Suez Canal (1869), and the defeat of France by Germany (1870-1871), which coincided with the gradual decline of the Qing Empire in China, creating an active dynamic for powers that were afraid of losing out to rivals in Asia. For French policy makers finding themselves in constant rivalry with Great Britain in Asia, one of the major goals was the creation of a French sphere of interest in southwest China, especially in the Chinese provinces of Yunnan, Kwangsi, and Kwangtung, along with neighboring French Indochina.

In the wider geographical context, France's sphere of interest in southwest China was the Gulf of Tonkin region, stretching in the west from the French port Haiphong across the Gulf of Tonkin and the island of Hainan into the northern part of the South China Sea, or Nan Hai (which precisely defined the eastern part of the Gulf of Tonkin), to the British crown colony of Hong Kong in the east (figure 1). With its major ports of Haiphong, Pakhoi, Hoihow, and Hong Kong, this maritime region was closely interlinked by shipping routes on which tramp shipping companies operated fleets of medium-sized coastal steamers under different flags. In contrast to liner shipping companies, these tramp shipping companies did not operate precise lines but shipped more or less regularly between ports, on the basis of trip charter or time charter contracts. Rivalry was intense due to high Chinese demand for rice, which was produced in French Indochina, and other agricultural products - especially vegetables and cattle from the island of Hainan - that were shipped on steam coasters via Hong Kong to large consumer markets in South China. 


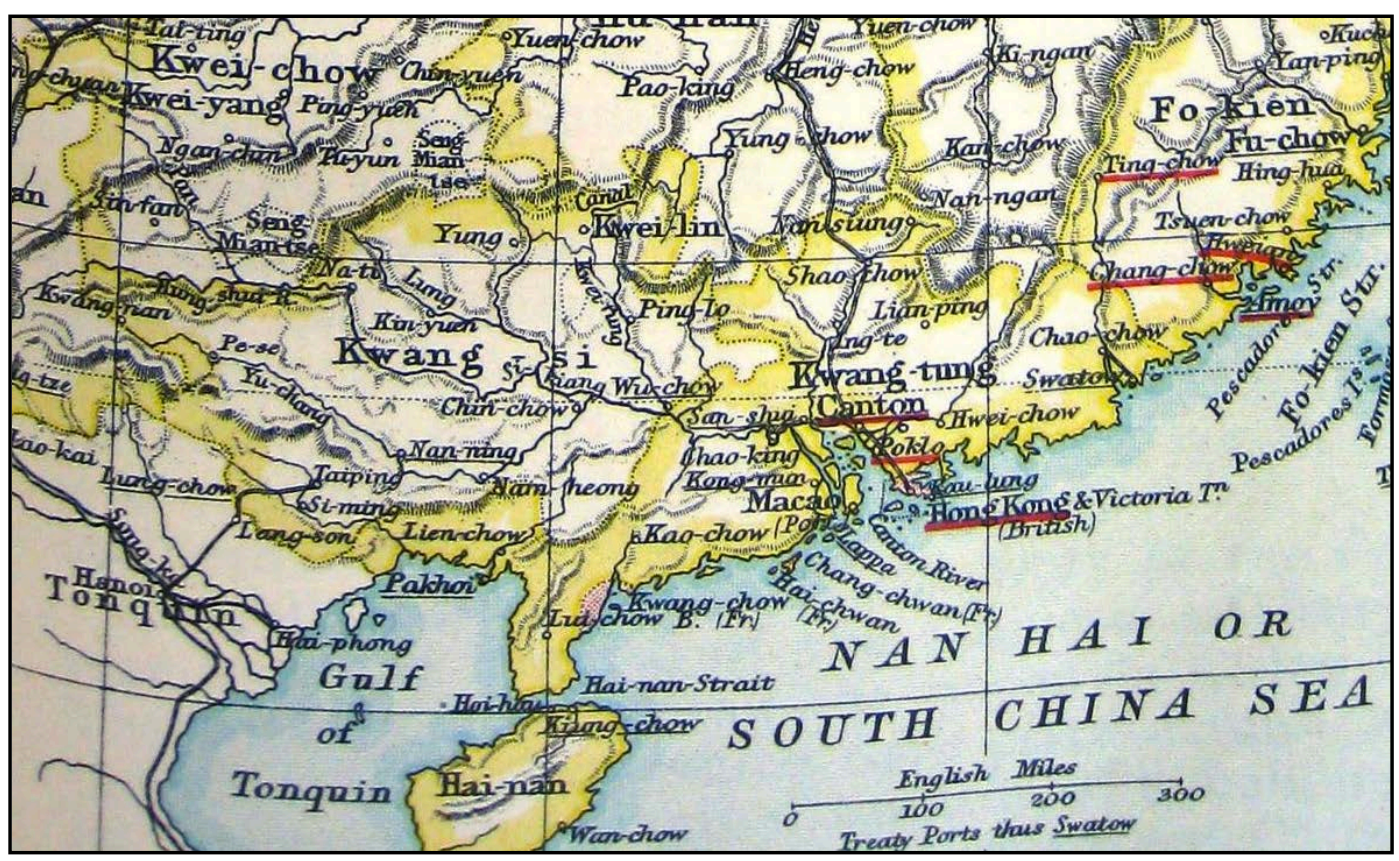

Figure 1. Detail of a map of China, showing the Gulf of Tonkin, early twentieth century. Source: The Hundred and Twentieth Report of the London Missionary Society (1915).

Scholars of Chinese business history have pointed out that, from 1860 to 1895 , coastal and riverine shipping was the most important Western economic activity in China. However, Western steam coasters predominantly depended on Chinese merchants' charters to transport bulk goods along the China coast, on its rivers, and between China and other ports in East Asia (Osterhammel 1989, 183). This was the field of business in which Chinese and foreigners started to "cooperate closely, both in the capitalisation of the shipping concerns and in the organisation of the services" (Allen and Donnithorne 1954, 131-132). Such practices were common in the treaty ports when Chinese merchants began investing in Western companies, starting in the 1870s. Economic historian David Faure has indicated that "possibly 70 percent of all Western shipping was financed by Chinese merchants." He concludes: "There can be little doubt that the bulk of this investment went through trusts that had been established via private channels" (Faure 2006, 51). The overall result of this practice was impressive: at the end of the nineteenth century, around 40 percent of the capital of Western firms in China - mainly active in shipping, banking, and cotton weaving, and to a lesser extent in insurance and manufacturing industries - was in Chinese hands, and Chinese merchants had become board members of numerous Western jointstock companies (Osterhammel 1989, 188). 
By presenting a case study in the wider context of business history in modern China, this article aims to develop a more differentiated picture of the spectrum of relations between foreign and Chinese firms on the level of material connections - in this case, shipping - and on the level of business culture (in this case, networks of trust). Based on archival evidence, this article demonstrates that a long-established sense of mutual trust between a Chinese and a Western firm was the precondition for close business cooperation. Such an association was established in 1896 between the Chinese firm Yuen Cheong Lee and Co. and the German firm Jebsen and Co. in the form of a joint agreement on the organization of tramp shipping services. That such a partnership was a rare combination at the time, even in Hong Kong, is confirmed in a private letter written by one of the German partners. The establishment of this partnership should be considered in the overall political context of heightened imperialist rivalries in China, and especially France's endeavors to create a sphere of interest in southwest China. To escape political pressure from both the French and Chinese governments, Chinese merchants entered a somewhat exceptional agreement with a German firm that was based primarily on mutual interest and trust.

Three main topics will be discussed in this article. First, France's new expansionist policy in southwest China from 1895 to 1898 provided the background for keen shipping rivalries among Chinese, French, and German firms competing for market shares. France's policy makers regarded French firms, such as the Tonkin Shipping Company based in Haiphong, as instrumental in fostering France's sphere of interest in the Gulf of Tonkin region. Such political considerations explain the motivation of French officials to politically and even militarily back owner Auguste Raphael Marty's claim to financial compensation from the Chinese government. This case demonstrates that the rather harmonious Sino-French relations in the period from 1895 to 1898-but particularly France's ambition for political and economic influence in southwest China - were crucial in providing Marty with strong support. It also shows that the Chinese and, at a later stage, German governments were prepared to tacitly accept the preponderance of French interests in southwest China, even before France formally acquired from China in 1898 her leasehold colony, Kwang-chow-wan (today’s Zhanjiang 湛 江), in Kwantung Province. For German policy makers in China, when Germany negotiated with China over the lease of Kiaochow Bay (situated in China's northeastern province of Shantung) in early 1898, it seemed vital to abstain from showing any substantial support for German shipping interests in South 
China, for fear of possible French political intervention in the ongoing Sino-German negotiations.

Second, Marty's profit-driven aspirations toward his main customers-Chinese merchants in Pakhoi and Hoihow shipping cargoes on foreign merchant steamers-severely harmed his business relations with them. His temporary monopoly in the market, which permitted him to fix freights at high rates, led to the establishment of the Chinese syndicate Tsap Yet (1895-1896), which boycotted his ships. In 1897, with French political backing, Marty succeeded in gaining financial compensation for his losses from the Chinese government, which recovered the sum from affected merchants through local authorities. The twofold damage to Chinese merchants caused by Marty's actions greatly damaged the French shipowner's reputation as a businessman. It is evident that foreign businesses in China backed by their own governments were able to make considerable short-term financial gains in the form of monetary compensation, but at the same time risked losing their Chinese client base when they were regarded as using unfair practices.

Third, the agreement on shipping services between the Chinese shipping company Yuen Cheong Lee and Co. and the German firm Jebsen and Co. arose in reaction to the interference of French and Chinese authorities in the shipping market. It made up for the prohibition of the Tsap Yet Syndicate by presenting an example of a partnership built on mutual trust. Such an association was possible only because both partners knew each other from many years of doing business. In order to escape political pressure, Chinese businesspeople were prepared to cooperate closely with a foreign firm. As outlined above, this partnership seems to have been rather unusual at the time.

The case study presented here describes an almost unknown episode in the history of France's presence in China and in East Asia, and particularly in China's political, economic, and maritime history. ${ }^{1}$ The reasons why it is so little known are probably twofold: first, as British interests in Hong Kong were not directly involved, there is hardly any documentation in Hong Kong government files or in English newspapers ${ }^{2}$; second, French and German government files appear to have rarely been consulted by historians working on the business or economic history of China.

The bulk of the material used for this article came from the Political Archives of the German Foreign Office (Berlin), which houses Chinese records of the boycott and its aftermath 
that were carefully documented by German consuls in Canton. I also found important evidence in the Diplomatic Archives of the French Foreign Ministry (Paris) and in the French National Archives of Overseas Territories (Aix-en-Provence), which possesses a large holding of French newspapers published in French Indochina. Published material from the National Library of China (Beijing) and unpublished documents from the private Jebsen and Jessen Historical Archives (Aabenraa, Denmark) shed further light on the case.

\section{France's New Expansionist Policy in China}

In the nineteenth century, France's foreign policy in the Far East was deeply influenced by its imperialist rivalry with Britain. National prestige played an important role when the French navy began operating in Far Eastern waters starting in the 1830s, mainly concerned with protecting Catholic missionaries due to the lack of any French commercial interests to safeguard. As a result of the First Opium War (1839-1842), in which British and French troops played an active role, France secured the Treaty of Whampoa (October 24, 1844) with China, a similar treaty to Britain's Treaty of Nanking; however, it could not establish a territorial foothold in China such as the British crown colony of Hong Kong. After the Second Opium War (18561860), which again saw French military intervention on the side of Britain, the Treaty of Tientsin (June 27, 1858) was enacted between France and China, conveying certain commercial and religious privileges. With the occupation of Saigon (1859), the major port in the Mekong Delta and at the time an integral part of the Kingdom of Annam, France's colonial presence in East Asia was established and, starting in 1862, the eastern part of the East Indian peninsula was successively acquired by treaties with the Annamite rulers.

In the mid-1880s, French foreign policy in the Far East took a decisively aggressive turn. Following the Sino-French War of 1884-1885, the Treaty of Tientsin (June 9, 1885) required China to give up its sovereignty over Annam and to accept a French protectorate over it. The protectorate of Annam and Tonkin was an important geopolitical change resulting in the permanent establishment of France at the border of southwest China. The main attraction of the Chinese provinces bordering Tonkin was their allegedly large and prosperous population, which constituted a potentially important market for French industry (Cady 1967, 29-38; Lee 1989, $12-$ 15; Brötel 1996, 223-340; Hsü 2000, 189-192). 
The next major turning point came ten years later. With the dismissal of German chancellor Otto von Bismarck (1890), the growing alliance between France and Russia (18931894), and the favorable economic situation, French policy makers came to a broad consensus on foreign policy issues, including colonial expansion (Stuart 1921, 5; Lee 1989, 141-173; Brötel 1996, 341-362; Hsü 2000, 325-330; Tixier 2008, 74-75; Bensacq-Tixier 2008, 309-313).

The new expansionist policy was embodied in the diplomat Auguste Gérard (18521922), who arrived in Peking in April 1894 to begin a vigorous, sometimes even aggressive, term as French minister in the Chinese capital (figure 2). The new minister was a highly politically minded person, having served in 1881-1882 as cabinet chief under Prime Minister Léon Gambetta, the proclaimer of the French Republic in 1870. In his memoirs Gérard wrote that his first obligation was to preserve and maintain all rights, concessions, advantages, and privileges that France had acquired since her first treaty with China in 1844. Charged with developing France's commercial interests in China, Gérard undertook an important economic mission (Gérard 1918, xxi-xxiii). Gérard's like-minded counterpart and chief in Paris, Gabriel Hanotaux (1853-1944), began his first term as France's foreign minister a month after Gérard arrived in Peking (figure 3). Gérard later praised Hanotaux for taking to heart his China mission and outlining his plan of action with great care (Gérard 1918, vi). The close interaction between the two French policy makers explains to a large extent the success of France's new offensive policy toward China from 1895 to 1898 .

The earliest opportunity for offensive action came with China's military loss to Japan in 1895, the most important turning point in China's history in the nineteenth century (Osterhammel 1989, 126). At the end of the Sino-Japanese War, China was forced to accept the terms of the Treaty of Shimonoseki (April 17, 1895), which included paying a huge war indemnity and ceding the Liaotung Peninsula to Japan. However, on Hanotaux's initiative, the so-called Tripartite Intervention of April 23, 1895, by Russia, France, and Germany was staged, forcing Japan to return the Liaotung to China in consideration of a further 30 million taels' indemnity. All three intervening powers expected to be well compensated by the Chinese. Finally, one of the obligations China had to accept was the payment of an indemnity of 200 million taels for which acquisition Russia and France offered their support. On June 10, 1895, Hanotaux received approval from the French parliament for a loan of 400 million francs provided by three French banks. This seemingly generous gesture was not made without ulterior 
motives; it was used by the foreign minister to actively expand France's influence and its interests in China. Such advantages were reaped by Paris in the Sino-French Convention of June 20, 1895, which secured for France extensive territorial and commercial concessions in South China, especially in the region neighboring the protectorate of Annam and Tonkin (Lee 1989, 150-152; Osterhammel 1989, 204-205; Brötel 1996, 388-434; Bensacq-Tixier 2008, 311-318).

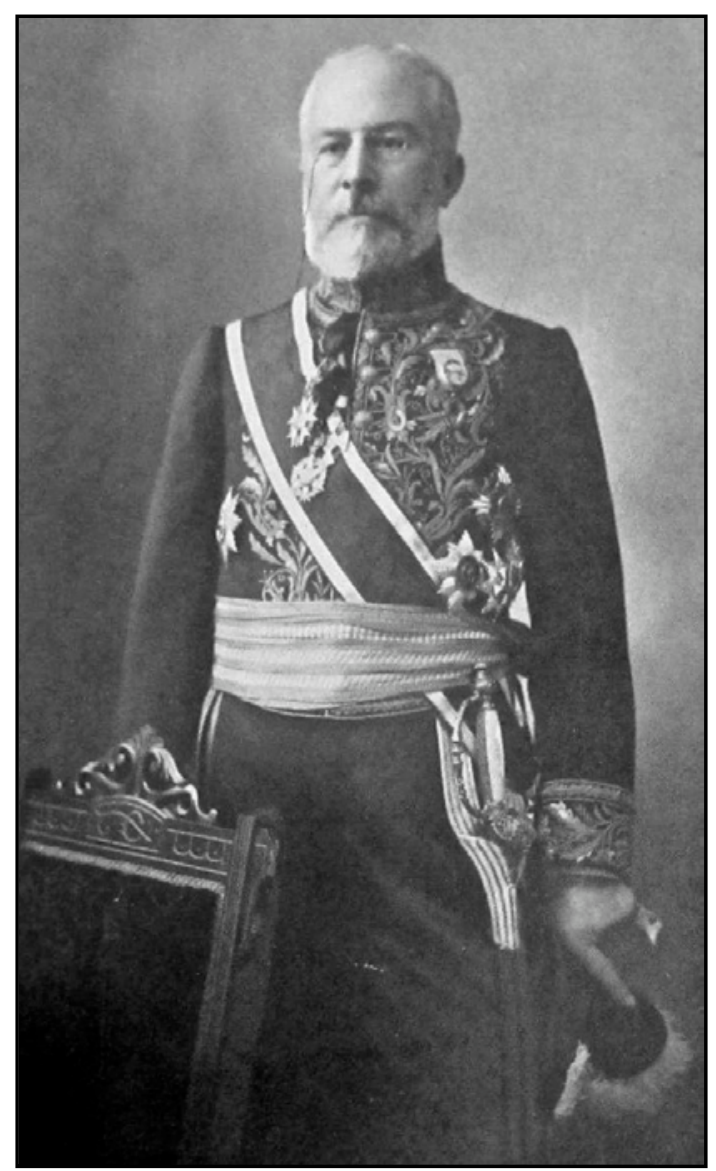

Figure 2. Auguste Gérard (1852-1922). Source: Gérard (1928, frontispiece).

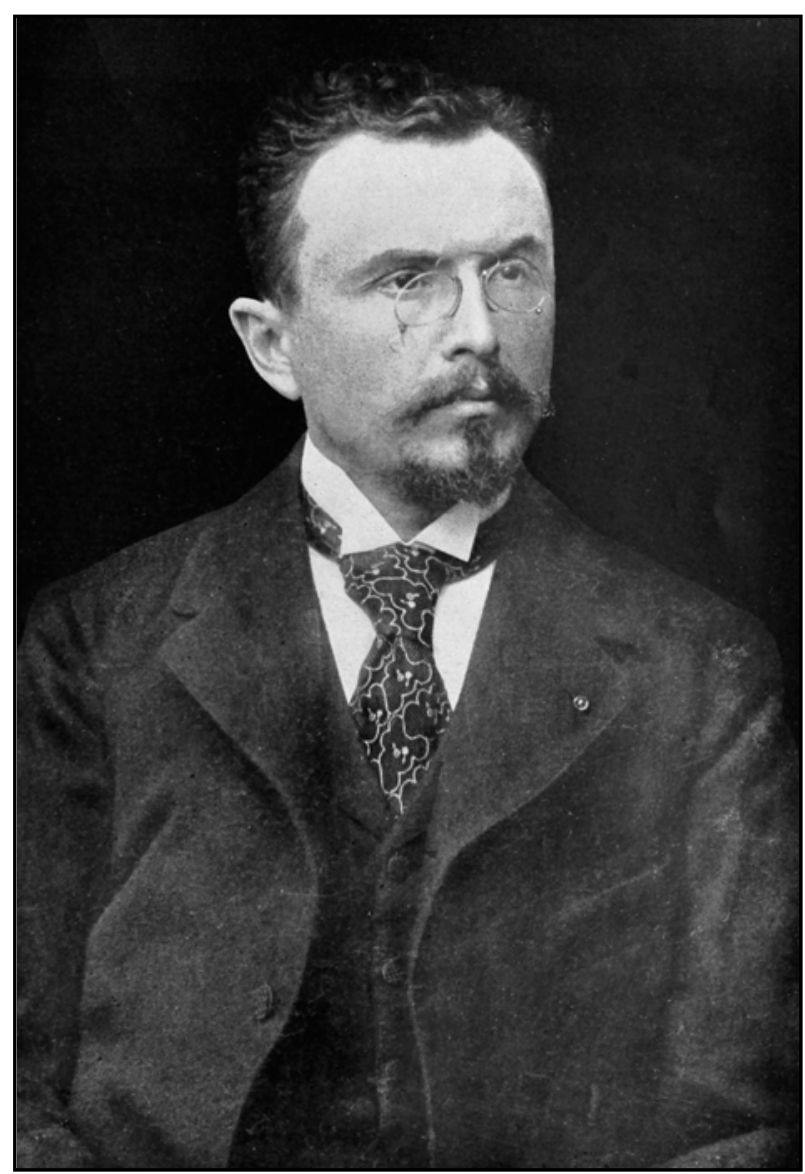

Figure 3. Gabriel Hanotaux (1853-1944). Source: Doubleday, Page and Company (1903, 3921).

An important concession by Peking was giving France the right to extend her railways from Indochina into Chinese territory. On June 5, 1896, the Chinese government signed an agreement with the French Compagnie de Fives-Lille regarding the construction of a railway line from between the border of French Indochina (in the region of Lang-son and Dong-dang) and the Chinese town of Long-chow in Kwangsi Province. Gérard called the event "a date in the history 
of the opening of China and an exclusively French date," because this railway concession was "the first one which had been granted by the Chinese government" to a foreign power (Brötel 1996, 456-466; Gérard 1918, 129-134). Consequently, the minister wrote:

The work begun in 1885 with the Treaty of Tientsin came thus to an end ten years later under the most proper conditions, not only to protect the security of our Indochinese possessions against new perils but to make Indochina the most direct and shortest way of penetration toward the south and the west of the great Empire. (Gérard 1918, 66-67)

However, as Gérard made clear, the principle of France's policy in East Asia was to maintain the integrity and independence of China. In return, as the minister explained, "China found herself linked for her own good, as for ours, to the politics of France and Russia . . from the ratification of the Treaty of Shimonoseki (May 8, 1895) until the end of 1897" (Gérard 1918, 51-52, 54).

In November 1897, the military occupation of Kiaochow Bay in Northeast China by German naval troops marked the beginning of fresh European imperialist policies acquiring leasehold colonies on the Chinese coasts. It also provided another opportunity for France's offensive action in China. With the occupation of Kwang-chow-wan ${ }^{3}$ in Kwantung Province, in April 1898, French policy in China entered a new and more aggressive phase that brought a clear end to the three-year period of Peking's collaboration and gratitude for France's political and financial support in 1895. The cooperative spirit of this rather harmonious period helps explain the strong influence of Gérard on the Chinese government. In this political climate, French companies interested in China were well aware of the important advantages that could be reaped from the friendly Sino-French relationship when it came to fostering their own business interests.

\section{Shipping Markets in the Gulf of Tonkin Region}

With the application of steam technology to ships in the nineteenth century, the sailing vessel was gradually replaced by the steam coaster, with its speedier journeys and more reliable timetables. Coastal and river steamers went on to transport large quantities of low-value but highbulk materials, a pattern that typified the nineteenth-century transport revolution not only in Europe and the United States but also in other parts of the world, including East Asia (Armstrong and Kunz 2002; Armstrong 2009, 91-102; Harlaftis and Theotakis 2002). With China, Japan, and other Asian countries still relying on junks as the primary means of water transportation, there was an excellent market for smaller oceangoing steamships that could transport 
commodities between the treaty ports on the China coast and link other port cities on the shores of the Southern Ocean (Otte 1930; Liu 1956, Liu 1964; Becker 2010).

In China, the right to engage in coastal shipping was given to the various treaty powers after the British Treaty of Tientsin in 1858. Since all treaty powers had a most-favored-nation arrangement with China in commercial conventions concluded after 1858, the right of cabotage was applied accordingly. However, coastal shipping went beyond the China Seas and closely connected northern maritime regions in Siberia and Japan with Southeast Asian regions in French Indochina, Malaysia, Singapore, Dutch East India, and the Philippines. In the main port cities of these regions, a combination of Western, Chinese, and local firms dealt with the regional and local import and export trade. Besides junks, small- and medium-sized steamships were frequently employed to connect the networks of commerce and finance in these regions. The British crown colony Hong Kong emerged as the most important port of call for intercontinental shipping lines and for all sorts of vessels employed in coastal shipping (Sze [1925] 1971, 131136; Tsai 1993, 23-26; Carroll 2005, 13, 33, 67-69; Meyer 2000, 83-87; Becker 2010, 249250).

Steamers engaged in coastal shipping were usually tramping, which was, as maritime historian Michael M. Miller explains, "a constant struggle to position ships where freight was abundant and competitors' ships were not, where rates therefore were high not low, where voyages contracted would not undercut arrival in time for seasonal trades, where going for a 'spot loading' was better than fixing a cargo in advance" (Miller 2012, 95). The same conditions applied to East Asia, where highly competitive shipping markets were usually divided into two different types of charter markets, the trip (or voyage) charter market and the time charter market. Under the first type of contract, which was typical of tramp shipping, the charterer hired the ship for only one voyage to carry his cargo at an agreed rate per ton. Under the second type of contract, the shipowner provided the crew and all other requirements for operating the ship. The charterer became the disponent owner and was allowed to send the vessel anywhere and load it with all kinds of merchandise. Under this type of contract, the charterer usually hired the ship at an agreed monthly rate over a period of three, six, or twelve months. The time charter option permitted the operation of regular lines in coastal shipping, something that was highly profitable when agricultural bulk cargoes (such as rice and other foodstuffs) were transported from agriculturally producing regions to consuming markets (e.g., from Burma, Siam, and 
French Indochina to Hong Kong and other major ports [Gipouloux (2009), 187-198; Becker (2010), 274-275; Becker (2012), 297-299, 317-319]).

The protectorate of Annam and Tonkin, France's new colonial acquisition (as of 1885) in French Indochina, provided a huge stimulus for French trading and shipping activities in the region's main port, Haiphong. One of the pioneers on the spot was the French merchant Auguste Raphael Marty (1841-1914) (figure 4), who had been based in Hong Kong as of 1874 with his own trading house, A. R. Marty et Cie, which also acted as the local agent of the major French firm Roque Frères. During the Sino-French War (1884-1885), Marty had provided provisions to French troops operating in Tonkin. In September 1886, he and his business partner, Jules d'Abbadie (1853-1904), established the shipping company Marty et d'Abbadie in Haiphong, making them the first French shipowners in the newly acquired colonial possession of Tonkin. The company became one of the most important French businesses in the Far East whose capital originated from French Indochina and not from France. ${ }^{4}$

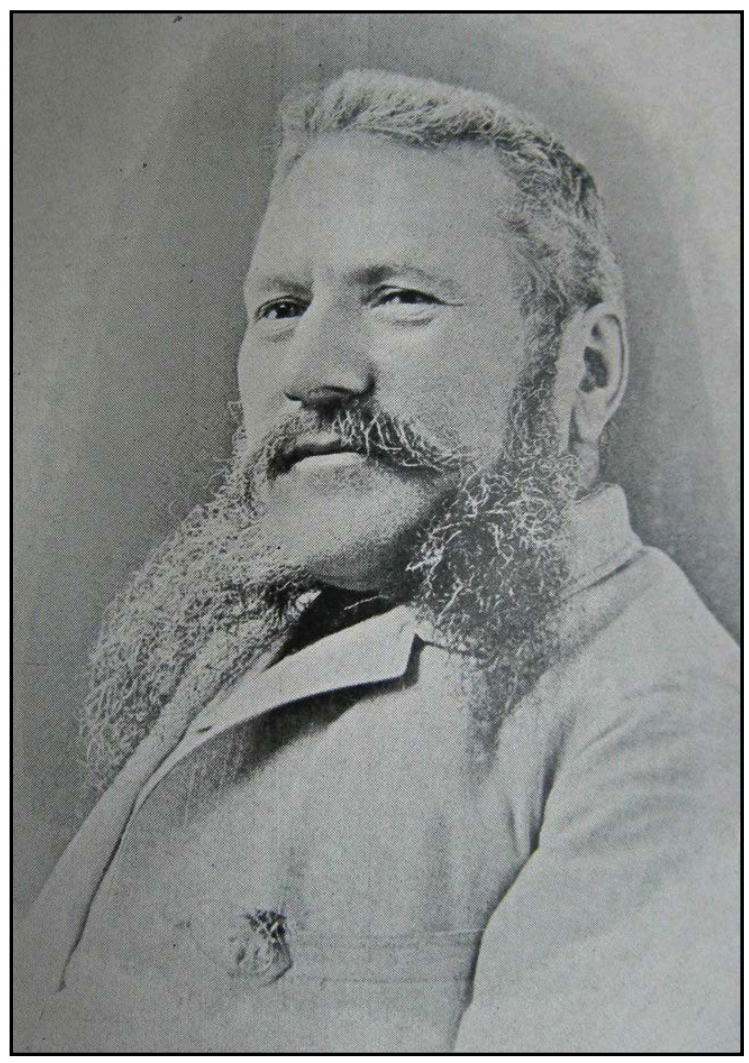

Figure 4. Auguste Raphael Marty (1841-1914). Source: Bulletin Trimestriel de la Société Amicale des Anciens Tonkinois (1940, 12). 
One of the first steps of Marty et d'Abbadie was to create the Subsidized River Shipping Service of Tonkin (Le service subventionné des correspondances fluviales du Tonkin). Starting in January 1887, this service operated mainly in the shipping of cargo and passengers along the Tonkin coast and on the Red River, the main river of Tonkin, including its principal tributaries, the River Claire and the Black River. For these regular scheduled services, which were essential to operating a network of traffic connections in Tonkin, the Government-General of Indochina paid a considerable subsidy to the service in which d'Abbadie served as director in association with Marty. ${ }^{5}$

The next step of Marty et d'Abbadie was to set up a regular oceangoing shipping service between Haiphong and Hong Kong, with occasional stopovers at Pakhoi and Hoihow. To efficiently operate the service in the Gulf of Tonkin region starting in early 1887, Marty frequently chartered small- and medium-sized steamships from German and Danish shipping companies, among them three coasters of the M. Jebsen Shipping Company (of which Jebsen and Co. in Hong Kong in March 1895 became sole agents). Therefore, shipping statistics from Pakhoi and Hoihow-which counted arriving and departing vessels by nationality-only partially reflect the important share of the shipping market that Marty held by engaging in such a practice. Table 1 provides a statistical overview of non-Chinese shipping in the port of Pakhoi during the last decade of the nineteenth century.

After the acquisition of two British-built merchant steamers in 1893, Marty was able to establish the Tonkin Shipping Company (Compagnie de navigation Tonkinoise). The firm operated the route between Haiphong and Hong Kong with the vessels Hanoi and Hongkong and also temporarily chartered the Danish steamers Ask, Frejr, and Activ (Bach 2014, 54-58). This service, under the French flag, was the only one of its kind on the China coast at this time, and it operated until 1900 without any subsidies from the French government. According to Marty, the line was established to comply with the political goals in South China of the French colonial government of Indochina and to make profits for his company. ${ }^{6}$ In this way, the Tonkin Shipping Company served France's political ambitions in the Gulf of Tonkin region, as well as Marty's business interests. The French company became a vital element in fostering France's political and economic interests in South China. Therefore, Marty could rely on the support of French policy makers should his business be threatened by any side. In 1906, an internal note of the Government-General of French Indochina stated that, in respect to Marty's firm, "there is an 
unquestionable political interest to favor the shipping company that carries most honorably the French flag in this part of the China seas."7

Table 1. Statistics of Foreign Shipping in Pakhoi (1890-1899)

\begin{tabular}{|c|c|c|c|c|c|c|c|c|c|}
\hline \multirow{2}{*}{ Year } & \multirow{2}{*}{$\begin{array}{l}\text { Number of Foreign } \\
\text { Steamers to Enter } \\
\text { and Clear Port }\end{array}$} & \multirow{2}{*}{$\begin{array}{c}\text { Tonnage of } \\
\text { Vessels }\end{array}$} & \multicolumn{5}{|c|}{ Percentage of Total Tonnage Carried under Each Flag } & \multicolumn{2}{|c|}{ Number of Passengers } \\
\hline & & & German & Danish & French & Norwegian & British & $\begin{array}{l}\text { Incoming } \\
\text { Passengers }\end{array}$ & $\begin{array}{l}\text { Outgoing } \\
\text { Passengers }\end{array}$ \\
\hline 1890 & 245 & 122,000 & & & & & & 1,700 & 3,000 \\
\hline 1891 & 224 & 109,000 & $60 \%$ & $39 \%$ & & $1 \%$ & & 1,225 & 2,700 \\
\hline 1892 & 203 & 89,300 & $51 \%$ & $47 \%$ & & $1 \%$ & & 1,600 & 1,400 \\
\hline 1893 & 285 & 128,000 & $49 \%$ & $49 \%$ & $1 \%$ & $1 \%$ & & 2,037 & 1,883 \\
\hline 1894 & 212 & 86,000 & & & & & & 1,931 & 1,700 \\
\hline 1895 & 204 & 105,000 & $38 \%$ & $56 \%$ & $3 \%$ & & $3 \%$ & 1,761 & 3,415 \\
\hline 1896 & 330 & 186,602 & $39 \%$ & $30 \%$ & $29 \%$ & $1 \%$ & & 2,300 & 2,221 \\
\hline 1897 & 214 & 113,732 & $39 \%$ & $24 \%$ & $36 \%$ & & & \multicolumn{2}{|c|}{$3,970^{*}$} \\
\hline 1898 & 210 & 108,000 & & & & & & 1,911 & 3,237 \\
\hline 1899 & 196 & 113,800 & $35 \%$ & & $63 \%$ & & & 2,155 & 6,098 \\
\hline Total & 2,323 & $1,161,434$ & & & & & & \multicolumn{2}{|c|}{46,244} \\
\hline
\end{tabular}

* Available data for 1897 does not differentiate between incoming and outgoing passengers Source: "The Customs Reports of Pakhoi from 1890 to 1899” (Gu and Li 1988, 100).

Such a combination of government and business interests was comparable to the contemporary relationship between the Japanese shipping company Nippon Yusen Kaisha (NYK) and the Japanese government. When analyzing the firm's history before the First World War, historian William D. Wray stated, "The public posture of acting on behalf of the state disguised the private struggle for advantage among competitors in the shipping industry" (Wray 1984, 344).

Given the strong position of German merchant steamers in the Gulf of Tonkin region, as demonstrated in the statistics of foreign shipping in Pakhoi, the appearance of the Tonkin Shipping Company meant that competition was opened. In late 1895, the Haiphong-based newspaper Le Courrier d'Haiphong, the most important voice of the port's French local interests, made this clear to its readers by commenting that Marty's shipping company had to use all its strength to establish the French flag in the Gulf of Tonkin, despite competition from foreigners, especially the Germans. ${ }^{8}$ 
However, Marty's direct competitor on the line to Hong Kong was the Chinese merchant Chau Kwang Cheong (周昆章, hereafter K. C. Chau) (?-1908) (figure 5). Chau owned the Hong Kong shipping company Yuen Cheong Lee and Co. (源昌利) and its branch house, Yuen Fat Lee and Co. (源發利), in Hoihow, Hainan's main port (also an open “treaty port”). Beginning in 1885, Chau frequently employed coasters of the M. Jebsen Shipping Company on time charter, conveying passengers and cargo to Hong Kong, Hoihow, and Pakhoi, the other treaty port in the northern Gulf of Tonkin. ${ }^{9}$

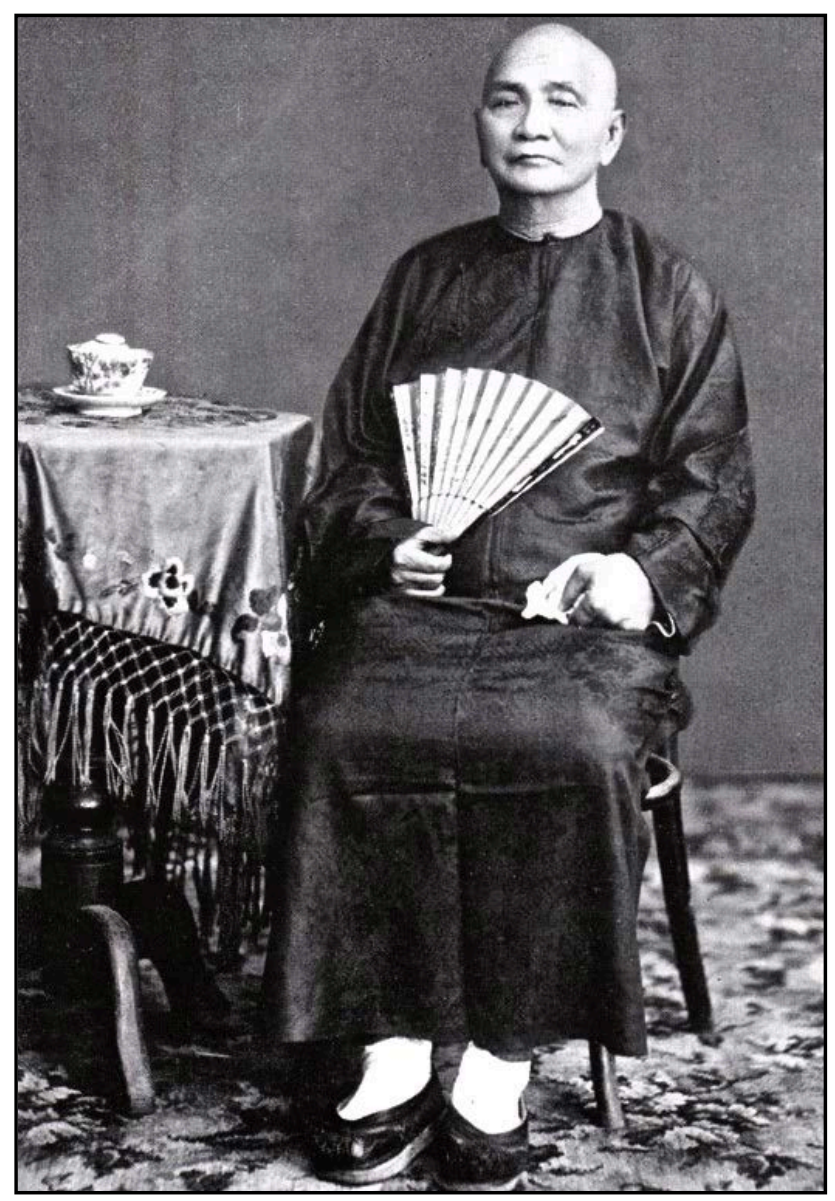

Figure 5. Chau Kwang Cheong (?-1908). Source: Jebsen and Jessen Historical Archives.

However, an exceptional situation arose during the final phase of the Sino-Japanese War (1894-1895), with the high demand for coasters to provide transport and supply provisions for Chinese troops. Chau's regular line between Hong Kong, Hoihow, and Pakhoi almost ended its operations after the shipowner moved his time-chartered vessels to other, more profitable routes 
in East Asia — especially on the route to and from Singapore - where steam tonnage could yield considerable gains. This led to very favorable conditions for Marty's shipping line between Haiphong and Hong Kong, which in the spring and summer of 1895 faced no competition. ${ }^{10}$ Consequently, the French shipowner put four ships on the line: his own two steamers under the French flag and two chartered Danish vessels, the Frejr and the Activ. Furthermore, to make the most of his temporary monopoly, Marty drastically raised the freight rates for all shipments of passengers and cargo. The sudden increase in transportation costs caused heavy losses for Chinese shippers in the ports of call who had no alternative but to ship their merchandise on Marty's coasters. ${ }^{11}$ The French shipowner's profit-driven business attitude caused a situation that provoked a strong reaction from the major Chinese commercial guilds at Hoihow and Pakhoi, whose principal goal was to watch over the commercial interests of its members; the reaction was a locally initiated boycott.

\section{The Tsap Yet Syndicate}

Boycotts were used by the Chinese from the 1840s to the 1930s in quarrels with foreign merchants over foreign goods. These boycotts targeted Japan, the United States, and Britain in particular, and a number of excellent studies (Morse 1909, 55-56; Liu 1956, 147-148; Remer 1966, 1-20; Tsai 1993, 182-237; Wong 2002) have examined the large boycott movements of the twentieth century, such as the 1905 anti-American boycott, which is usually seen as the beginning of this phenomenon. However, boycotting has a longer history in China, with local boycotts of the goods or merchants of a particular foreign nation, and, starting in 1842, there seem to have been occasional local boycotts of the merchants of certain countries. These early boycotts can be regarded as the weaponry of one of the most powerful and organized social groups in late Qing China, namely the Chinese merchant guilds. Guild members entered into agreements that involved ceasing to purchase or deal in goods, or abstaining to use ships of the boycotted country. Unlike the political boycotts that followed the 1905 anti-American boycott, local boycotts - often called "taboos" in English-language sources - were not directed against the ships of a particular nation, but against those of a particular company.

Confronted with an exceptionally unfavorable situation, the worst-hit Chinese guilds in Hoihow and Pakhoi reacted quickly to the crisis and, in the autumn of 1895, established the 
syndicate Tsap Yet Company [also known as Chi I Company or Chak Yik] (集益公司), with the sole purpose of breaking Marty's monopoly. After statutes had been set up, the syndicate commenced its operations in Pakhoi in October 1895, chartering two steamers under the German flag, the Triumph of the M. Jebsen Shipping Company, of which Jebsen and Co. in Hong Kong were agents (figure 6), and the Cosmopolit of the Wahl Shipping Company, of which Wieler and Co., German shipbrokers in Hong Kong, were agents. All partners of Tsap Yet were obliged to ship their cargo exclusively on the two vessels, according to the statutes, and the freight rates of the two syndicate steamers were set lower than Marty's. ${ }^{12}$ With these arrangements, the boycott began.

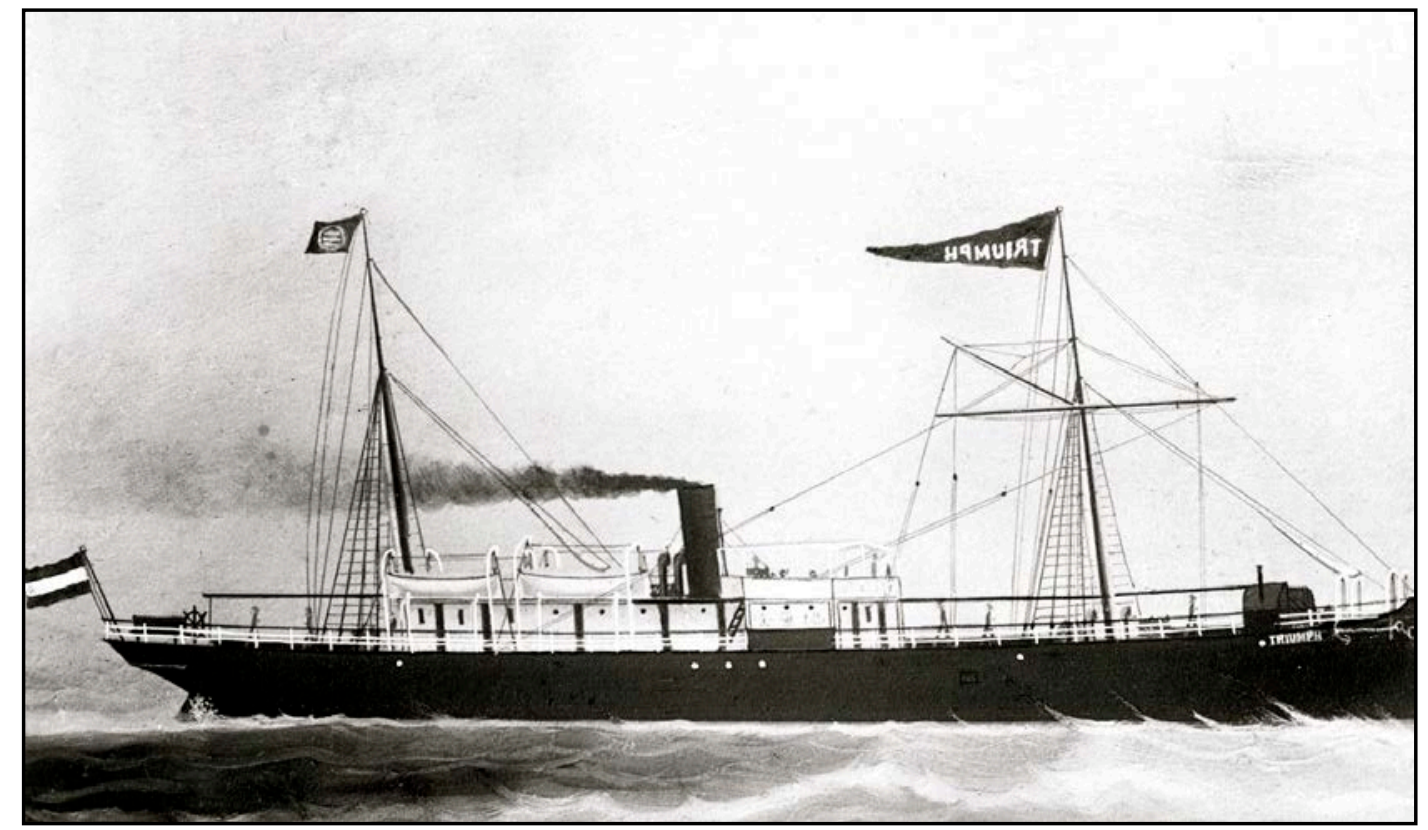

Figure 6. Steamer Triumph of the M. Jebsen Shipping Company, in service from 1881 to 1899. Source: Jebsen and Jessen Historical Archives.

Concurrently in French Indochina, Marty's Tonkin Shipping Company was also boycotted. The Chinese company Kouang-Yun-Pang, based in Mengzi, Yunnan, obliged its members in China and in Tonkin by statute and under penalty of punishment not to load any cargo onto Marty's river ships making transit voyages on the Red River across the Chinese province of Yunnan. It seemed a well-coordinated action on the Chinese side to augment the effectiveness of the boycott by targeting both Marty's ocean and river shipping companies. ${ }^{13}$ 
However, the consulted sources provide no more information or evidence to shed further light on this incident.

On October 15, 1895, the French shipowner experienced the effects of the boycott in Chinese waters when one of his chartered ships called twice at Hoihow and Pakhoi and received absolutely no cargo. Although Marty immediately reacted by considerably lowering his freight rates, his ships were boycotted by Chinese shippers in the ports of Hong Kong, Hoihow, and Pakhoi, causing huge financial losses for the Tonkin Shipping Company. ${ }^{14}$

\section{France's Diplomatic Intervention}

In view of this situation, which he regarded as unfair to his business, Marty sought political support from French officials by contacting the French consul in Canton and the Governor-General of Indochina. Both applications were referred to Gérard, who was chiefly responsible for France's political exchanges with the Tsungli Yamen, the Chinese equivalent of the Foreign Ministry before 1901, which from 1861 was in charge of China's foreign affairs. Given the aforementioned strong interest of French policy makers in supporting Marty's shipping line in order to foster France's interests in South China, Gérard did not hesitate to take up the issue. In order to provide a sound reason for his complaint, the minister based his protest on the Sino-French Treaty of 1858 (notably Article 14), pointing to the alleged violation of the liberty of commerce by the Chinese syndicates in Kwangtung and Yunnan. ${ }^{15}$

In light of the cooperative spirit when France's diplomatic influence on China was at its peak, it was not surprising that the Chinese government reacted positively to Gérard's complaint. Acknowledging the French position in principle and also the minister's demand for a speedy solution to the problem, the Tsungli Yamen instructed Tan Chung-lin (譚鍾麟), viceroy of Kwangtung and Kwangsi, and Wang Huai-sen (黃槐森), governor-general of Yunnan Province, to ban both syndicates. At the same time, Gérard approached Augustin Juline Fourès, acting Governor-General of Indochina, recommending that he inform Chinese merchants in Yunnan about the ban and take stern measures against members of Kouang-Yun-Pang residing in Tonkin. ${ }^{16}$

In the meantime, Marty, being well aware of France's politically driven backing of his business interests, had gone even further by getting in touch with Camille Gauthier, the French 
vice-consul in Pakhoi and one of the most fervent supporters of French interests in South China. Informing Gauthier about the boycott, the shipowner claimed damages of 50,000 taels (approximately 76,500 Mexican dollars, roughly the same amount in contemporary U.S. dollars), in view of the fact that his ships had received no cargo due to competition from the Tsap Yetchartered steamers. When contacting local Chinese authorities in Pakhoi on the issue, Gauthier took the same line as Gérard by pointing to Article 14 of the Treaty of 1858 and announcing that Marty could claim damages should there be no solution to the crisis. Under intense pressure from Chinese officials in both Canton and Pakhoi, Tsap Yet was immediately dismantled. In early November 1895 the syndicate's statutes were scrapped, and new regulations were drafted by legal experts in Hong Kong. In the newly established Chinese company in Hong Kong that operated under the same name,${ }^{17}$ the German-owned trading firm Schomburg and Co., based in Pakhoi, became a shareholder as well as the formal shipping agent of the Triumph and the Cosmopolit. $^{18}$

However, such steps were not accepted by the French, who regarded the new Chinese company as evidence that Tsap Yet was still in operation but now masquerading under the protection of a German firm. At the consul's request, Liu Ch'i-Hsün (劉齊潯), prefect of Limchow, dispatched an official to the port to take part in the meeting of the joint Sino-French commission of December 4, 1895, with Gauthier, Marty, and no fewer than twenty local Chinese merchants. When the Chinese official pointed to the fact that Schomburg and Co. was now the agent of the German ships, the consul refused to acknowledge this, stating that Tsap Yet still existed and demanding remuneration for Marty's financial losses. When discussions ended without the result the French had hoped for, Gauthier reverted the matter to Gérard, who once again approached the Tsungli Yamen (Chen 2008a).

According to E. L. B. Allen, British consul in Pakhoi, the Chinese government tacitly agreed with the French position: "It is probably not an unfair inference from this step on the [Tsungli] Yamen's part that they admitted the French contention as regards an infraction of the Treaty Article." The British consul even backed the French stance by stating, in a letter dated January 24, 1896, that "Schomburg \& Co. have for some two months first lent the cover of their name to a coalition whose object was to prevent free choice of steamers by the use of deterrent regulations framed to secure a monopoly to the coalition steamers." ${ }^{\prime 19}$ Since Allen was also 
acting consul in charge of German interests at Pakhoi due to the lack of any consular representation on behalf of Germany in this port, his remarks on the attitude of Schomburg and Co. carried enormous weight because he possessed insider knowledge regarding German business interests in the Gulf of Tonkin region. Allen also pointed to the allegation of a Chinese merchant at the meeting of December 4, 1895, that the statutes of Tsap Yet had been drafted by Schomburg. If that was true, the French had every reason to believe that the association between local Chinese merchants and the German firm was merely a new complot directed against the French shipowner.

In the meantime, diplomatic pressure had led to the proclamation of January 12, 1896, in which Prefect Liu declared the dissolution of Tsap Yet. ${ }^{20}$ However, at Gérard's request, the joint Sino-French commission reconvened at Pakhoi on January 15, 1896, to reinvestigate the matter and achieve a workable solution for both sides. The Chinese side sent a representative of Governor-General Tan and Prefect Liu; the French side was again represented by Gauthier and Marty. Faced with the presence of the French gunboat Alouette, which had been deliberately dispatched to intimidate the Chinese negotiators, the local authorities yielded to the threat and ordered Chinese shippers to ship their cargo solely on the coaster of the Tonkin Shipping Company anchored in the harbor. Consequently, Marty's vessel cleared the port fully loaded. It was obvious to observers that Chinese local officials had gone beyond their authority when forcing the shippers to act thus. ${ }^{21}$

During the approximately weeklong negotiations of the Sino-French commission, Gauthier proved to be strongly politically minded by ardently supporting Marty's damage claim of 100,000 taels for losses caused by Tsap Yet. He also demanded cancellation of the time charters of the two German coasters and a ban of any future shipping on these vessels. The Chinese officials rejected such claims, pointing out that the German firm Schomburg and Co. was the agent of the German steamers and thus it was a matter for the two rival French and German shipping companies to work out. ${ }^{22}$ The Courrier d'Haiphong, a strong advocate of the French position, called the statement a "crude subterfuge" that would mislead no one. ${ }^{23}$

Dr. Wilhelm Knappe, German consul at Canton, commented later that the French had gone too far in their demand for a ban: "It would mean, if not forever, but for a number of years a French monopoly in the said two ports because in the face of such pressure from the authorities, the Chinese merchants would never dare to charter or load on another steamer." ${ }^{24}$ 
However, a firm agreement was reached when Chinese officials required Chinese shippers in Pakhoi to commit in writing to submit to the destruction of the Tsap Yet statutes, to readily accept severe punishment, and to recover damages should ships of the dissolved company return to Pakhoi. In consequence, Tsap Yet formally ceased to exist as of January $22,1896 .{ }^{25}$ The French had indeed achieved a remarkable diplomatic success by pushing through their position vis-à-vis the Chinese.

The Germans were quick to react. Facing a situation in which Chinese merchants would thereafter not charter or load any of their ships, Jebsen and Co.- in a tactical move comparable to Marty's-asked the German consul for political support. Knappe in turn contacted Viceroy Tan, stressing the general principle of liberty of commerce granted to all shipping and trading businesses in Chinese treaty ports and urging him to immediately issue an official proclamation informing Chinese shippers that it was their free right to ship goods on whatever merchant vessel they desired. ${ }^{26}$ Tan agreed and accordingly instructed Prefect Liu, who had the statement published at the end of January 1896. However, the prefect undermined his instructions by sending a messenger around the merchants in Pakhoi to pass by word of mouth that Chinese shippers were not allowed to ship on the two German steamers in question. ${ }^{27}$

His counteraction coincided with the French decision to redispatch the Alouette to Pakhoi in early February 1896 in order to forcefully prevent the loading of the German vessels. In view of such constraints, the Pakhoi merchants gave in: the time charter of the Triumph was cancelled on February 1, 1896, and that of the Cosmopolit soon thereafter, resulting in huge contractual penalties for shippers. ${ }^{28}$ It was clear that the merchants had yielded to the combined political and military pressures.

\section{Sino-German Business Cooperation}

The continuing crisis in the shipping market of southwest China caused by Marty's aspirations and France's interest in backing his business was an important factor in the fostering of French influence in the Gulf of Tonkin region, and it resulted in a noteworthy Sino-German business cooperation. The initiative came from Jebsen and Co. and its co-owner Jacob Jebsen (figure 7), who paid a personal visit to Pakhoi in early 1896 to discuss the situation with E. L. B. Allen, the British consul in charge of German interests. Jebsen's correspondence from the time is silent on the subject; it appears the German shipowner wished to keep the issue confidential in 
order to avoid interference from any side. His private mission to Pakhoi is not even mentioned in his personal memoirs, in which the events of 1895-1896 are briefly presented. ${ }^{29}$ However, the major contents of the visit were divulged by Allen to Prefect Liu and later to his German counterpart in Canton, Consul Knappe. According to Allen's report, Jebsen announced his intention to establish a Jebsen \& Co. shipping line between Hong Kong, Hoihow, and Pakhoi, with the steamers Doris, Triumph, and Michael Jebsen. When he promised not to charter his ships to others but to operate them solely under the name of his company, it was obvious that he wanted to avoid giving the French the impression that he intended to employ tactics similar to those that Schomburg \& Co. had used as agents of Tsap Yet. Therefore, Jebsen asked Allen to issue an official proclamation informing Chinese shippers that it was their right to load the Jebsen vessels with their cargoes; his request was followed up when Consul Allen contacted Prefect Liu. ${ }^{30}$ With the same intention in mind, Consul Knappe approached Viceroy Tan, who gave corresponding orders to Liu. Under such pressure, the prefect finally issued a public announcement that made it clear that shippers could ship goods on any vessel of their choice. ${ }^{31}$

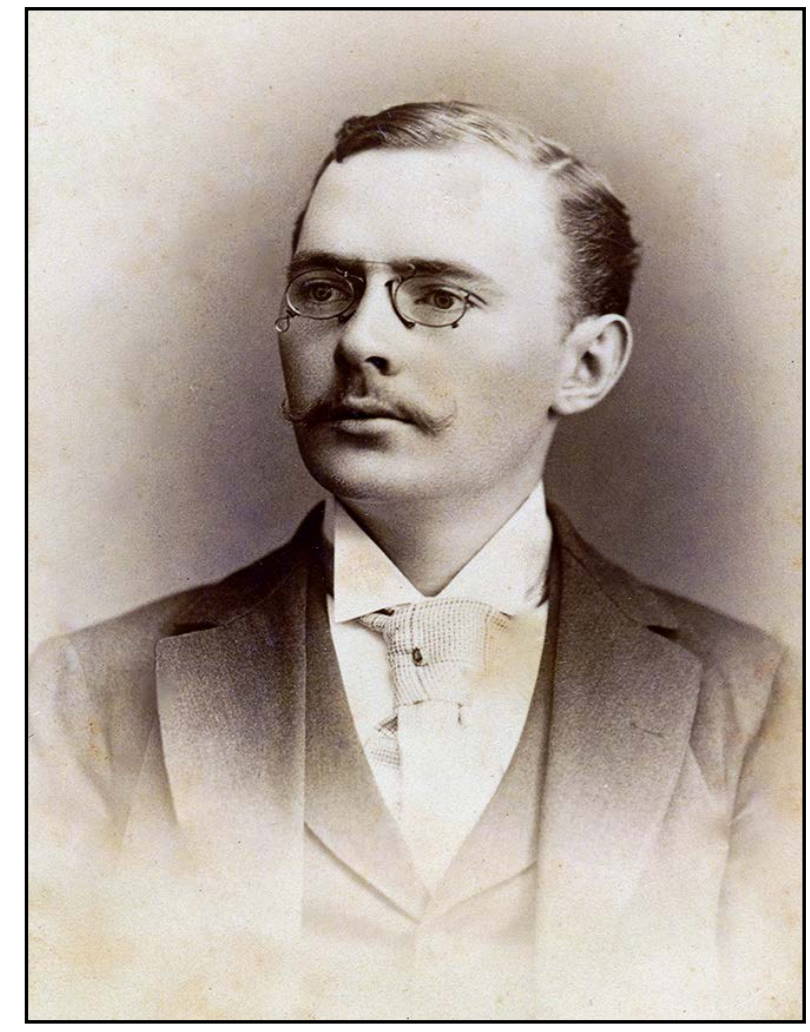

Figure 7. Jacob Jebsen (1870-1941). Source: Jebsen and Jessen Historical Archives. 
The proclamation brought about the desired result: the Doris (figure 8) and the Triumph were soon charged with shipments of merchandise from Pakhoi merchants. Indeed, Jacob Jebsen could depend on the support of the Chinese for two reasons: First, it was evident to the shippers that the earlier crisis had been caused by Marty's attempt to exploit his temporary monopoly in the regional shipping market to their economic disadvantage. Second, it was also plain that the crisis had been exacerbated by the involvement of French officials, who observably had their own political intentions in mind when supporting the interests of the Tonkin Shipping Company. There was a possibility that the French could again, and at any time, interfere with commercial freedom by applying pressure on the Chinese government and local Chinese authorities to ship goods on Marty's vessels. The best solution was to rely on a foreign shipping company that was - in contrast to Tsap Yet - immune from pressure from the Chinese and French authorities and was firmly backed by German consular staff in China in order to secure reliable shipments. Therefore, Jebsen's idea was met with support but on the precondition that the arrangement should be in the form of a partnership with K. C. Chau, the former operator of the line. ${ }^{32}$

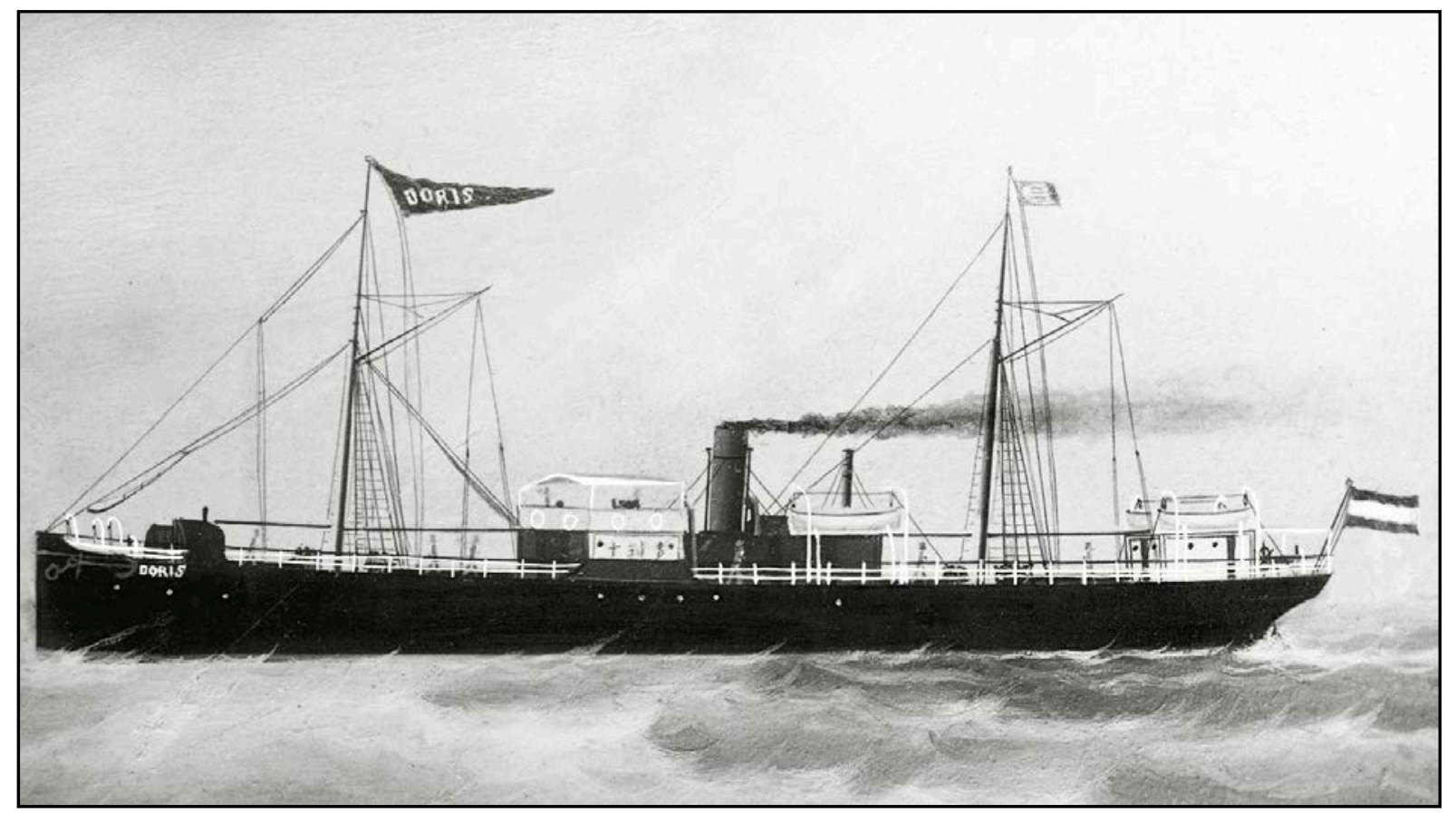

Figure 8. The steamer Doris of the M. Jebsen Shipping Company, in service from 1882 to 1897. Source: Jebsen and Jessen Historical Archives. 


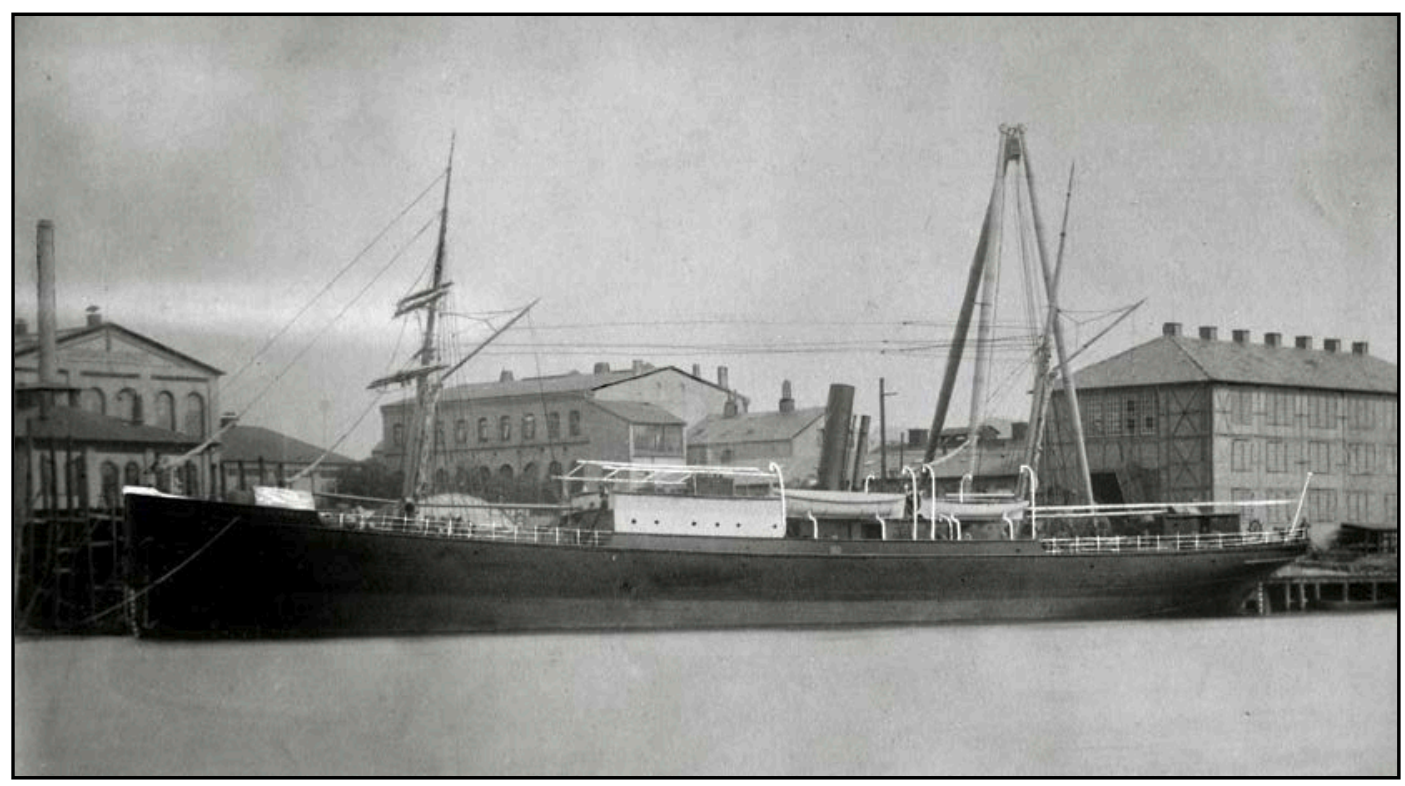

Figure 9. The steamer Michael Jebsen of the M. Jebsen Shipping Company, in service from 1889 to 1904. Source: Jebsen and Jessen Historical Archives.

The plan was kept strictly confidential; the consulted correspondence on the German, French, and Chinese sides is entirely silent on the matter. Even in Knappe's detailed memorandum of December 1896, in which the events were chronologically narrated for the German minister in Peking, the consul mentions only that, after the cancellation of the charters of the Triumph and the Cosmopolit, Jebsen and Co. operated "on their own account" the Triumph, the Doris, and the Michael Jebsen (figure 9) on the route between Hong Kong, Hoihow, and Pakhoi. ${ }^{33}$

On February 3, 1896, the two companies entered into an agreement in which the Germans would "undertake the line of steamers running between Hoihow, Hong Kong \& Pakhoi . . on their own account" and appoint Chau's firm in Hong Kong and its branch house in Hoihow as "their agents for securing cargo and doing the other ship's business." To prevent any mutual competition in the line, Yuen Cheong Lee and Co. assented "not to charter any steamers or accept the agency or to be otherwise interested in any steamers trading to Hoihow and Pakhoi without the express consent" of Jebsen and Co. ${ }^{34}$

Mutual consent had been quickly gained; the partners trusted each other after having done business together for ten years, during which a number of Jebsen's coasters had frequently been chartered by Yuen Cheong Lee and Co. In 1908, Jebsen confirmed in a letter that the 
partnership of his company with Chau "was only based on personal trust to him."35 Mutual interest, and especially mutual trust, were undoubtedly the basic propelling factors and the necessary preconditions for entering this business association. Such trust between people in economic exchanges has been described as having a mutual confidence that others will not exploit any adverse selection, moral hazard, holdup, or other vulnerabilities that might exist in a particular exchange. The existence of strong trust between partners is especially regarded as a source of competitive advantage when such a form is relatively rare among a set of competitors (Sabel 1993, 1133; Barney and Hansen 1994, 176, 188-189).

Indeed, the partnership between K. C. Chau, and later his eldest son, Y. T. Chau, was a rare combination, giving Yuen Cheong Lee and Co. a unique position in Chinese business circles in Hong Kong. That the partnership between Chau and Jebsen was somewhat exceptional is evident in a comment that Jacob Jebsen made in a letter from late 1900 highlighting the special situation of Chau's firm. Reminding Heinrich Jessen, his German business associate, (figure 10) of their shared impression that K. C. Chau had "a rather isolated position among Chinese commercial circles in Hong Kong," Jebsen was not optimistic about establishing new business contacts through him. ${ }^{36}$ The remark shows that K. C. Chau's partnership with Jebsen and Co. was a relatively unusual association that set the Chinese firm apart from its competitors. ${ }^{37}$

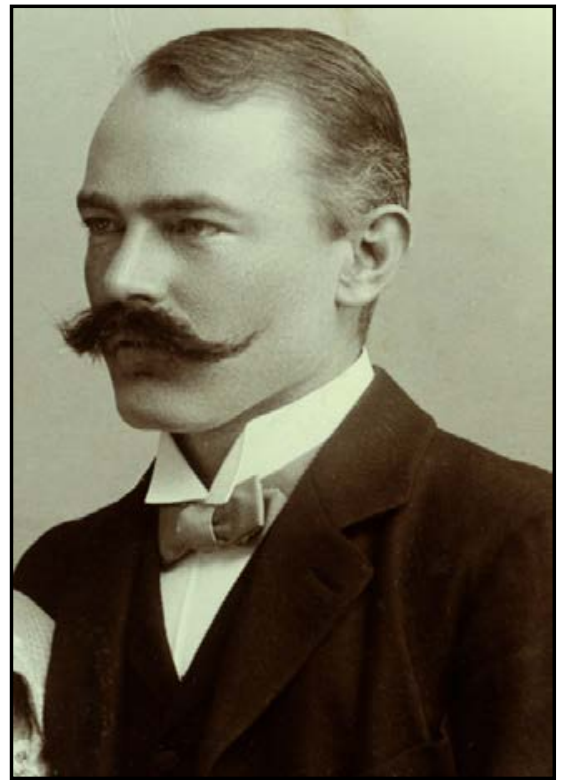

Figure 10. Heinrich Jessen (1865-1931). Source: Jebsen and Jessen Historical Archives. Source: Jebsen and Jessen Historical Archives.

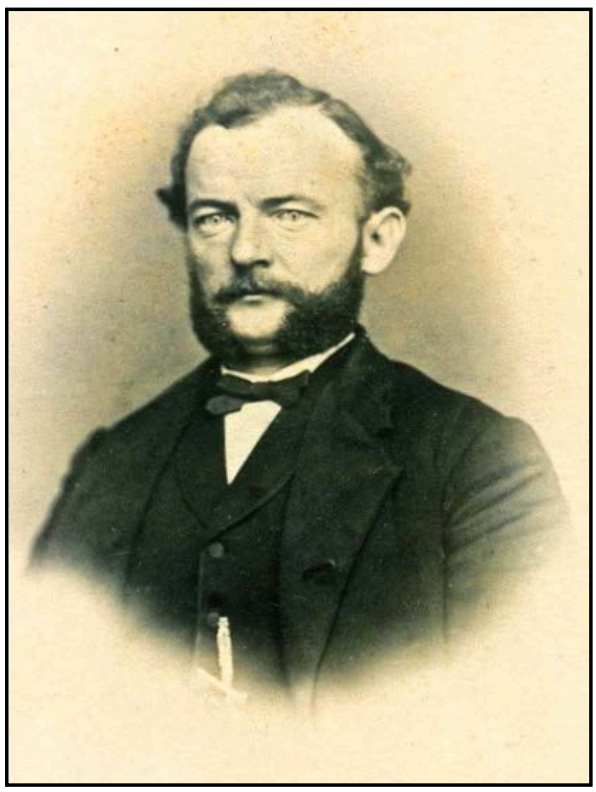

Figure 11. Michael Jebsen (1835-1899). 


\section{The Sino-French Compromise and German Reactions}

After the public proclamation of Prefect Liu in February 1896 that Chinese merchants could ship goods with any vessel of their choice, Marty's steamers received hardly any cargo. However, fearing fresh French political intervention, Chinese local authorities and shippers in Pakhoi and Hoihow finally agreed to provide Marty's steamers a minimum share of their cargo. ${ }^{38}$ With such small profits the French shipowner saw no solution to the crisis and, in late February 1896, decided to go to Peking to personally ask Gérard for stronger political support. He was received coldly, with the minister remarking that everything would be done and suggesting an understanding between the concerned parties, which Marty furiously and categorically refused, even after Foreign Minister Hanotaux intervened. ${ }^{39}$ The French policy makers apparently wanted to put an end to the matter, which had the potential to seriously damage the heretofore harmonious Sino-French relations.

In April 1896, Marty's position was further weakened when Consul Gauthier, one of the most fervent supporters of France's interests in South China, left his post in Pakhoi on account of bad health. However, shortly before his departure, Gauthier had sent a letter to Prefect Liu stating his conviction that the Jebsen steamers were owned by Tsap Yet masquerading under the German flag and concluding that the conditions of the Pakhoi shipping market remained the same as before Tsap Yet's dissolution. ${ }^{40}$ Aware of such official backing, Marty remained in Peking in order to keep up the pressure, which finally led to a new French diplomatic initiative. On June 17, 1896, Gérard approached the Tsungli Yamen, maintaining that Tsap Yet was still in operation and demanding compensation of 100,000 taels for Marty. ${ }^{41}$

In their reply, the Chinese ministers stressed that the Triumph's German nationality gave it the right to ship goods and passengers without the interference of the Tsungli Yamen. They also called Marty's claim "absurd" and advised the shipowner not to make Chinese merchants responsible for his unsuccessful business and to change strategies in order to make his company operate effectively. ${ }^{42}$ Their resolute position caused Gérard to pay a personal visit to the Tsungli Yamen on August 17, 1896, where he found the ministers prepared only to send a special commissioner to Hoihow to investigate the matter (Chen 2008b).

In their meeting with the commissioner on October 26, 1896, the Hoihow merchants emphasized that the three steamers on the line were owned and operated by Jebsen and Co. However, due to pressure from Peking's commissioner, they finally signed a guarantee 
promising to provide cargo to any vessel in an open and fair manner. ${ }^{43}$ By doing so, it is clear that the merchants hoped to demonstrate their goodwill toward the French.

The Sino-French compromise of October 26, 1896, presented a challenge to Jebsen and Co., to which the German firm reacted in a joint political and economic approach: First, in the autumn of 1896, Michael Jebsen (figure 11), owner of the M. Jebsen Shipping Company and at the time a member of the German National Parliament (Becker 2012, 371-555), appealed to Foreign Minister Adolf Baron Marschall von Bieberstein, with whom he was on friendly terms. Consequently, Edmund Baron von Heyking, the German minister in Peking, was instructed by Berlin to communicate with the Chinese government should local authorities in Hoihow and Pakhoi intervene on behalf of Marty's vessels and hinder free trade in the regional shipping market. $^{44}$

Second, and simultaneously, Jebsen dispatched more coasters to Haiphong and Tonkin in order to ship large amounts of rice to Hong Kong and increase competition against Marty. As the German firm explained, it wanted to induce Marty to come to a joint solution for the ongoing crisis in the Pakhoi and Hoihow shipping markets. However, with Jebsen yielding good profits in the Haiphong rice trade and Marty suffering huge losses, the mood of the French again deteriorated. ${ }^{45}$ This time it was Véran Dejoux, the new consul in Pakhoi, who had a complaint to make about the alleged continuation of Tsap Yet. He presented new figures that showed the Chinese merchants favoring Jebsen's steamer Triumph and at the same time disadvantaging Marty's chartered Danish vessel Ask when loading in Hong Kong on October 21-22, 1896. Consul Knappe concluded that it was another attempt "to influence Chinese authorities in order to suppress freedom of shipping and to force merchants to ship their cargo on French steamers. ${ }^{\$ 46}$ However, French officials did not give up leveraging their position on behalf of Marty's demands.

\section{Marty's Financial Compensation}

On November 17, 1896, on Marty's behalf, Consul Dejoux made a new suggestion to Gérard at the Tsungli Yamen: the dispute should be settled locally by appointing negotiators for both parties and having the Imperial Maritime Customs (IMC) Commissioner of Pakhoi act as a neutral third party during the talks (Sun and Liu (2003). Upon the instruction of Sir Robert Hart, 
inspector-general of the IMC, Commissioner J. F. Schoenicke made a preliminary investigation into the matter and concluded that Marty's firm was not eligible for any compensation. ${ }^{47}$

The Sino-French commission chaired by Consul Dejoux and accompanied by Gaston Kahn, French consul at Hoihow, reconvened in Pakhoi on January 14, 1897. The Chinese side was represented by the prefects of Limchow and Kaolien-chi, and two other officials took part in the talks, during which they were frequently instructed by telegrams of Viceroy Tan (pressured by Consul Knappe) not to harm Germany's or Jebsen's interests. Initially the French claimed compensation of 100,000 taels (approximately 153,000 Mexican dollars) for Marty, but upon meeting firm Chinese opposition, they suddenly increased the sum to 674,000 Mexican dollars, stating that the shipowner had suffered losses even after Tsap Yet's formal dissolution. On January 22, 1897, Marty unexpectedly turned up in person to boost his position, provoking vehement protests from W. N. Morehouse, customs commissioner at Pakhoi, who put into doubt Marty's statistical descriptions of freights. When discussions ended fruitlessly, Sir Robert Hart, despite mostly disagreeing with the French position, advised the Chinese government to swiftly pay the entire requested compensation, which had been fixed at about 760,000 Mexican dollars, to avoid any possible future claims from Marty. ${ }^{48}$

Gérard took up the ball with the clear intention to settle the case permanently before ending his mission and returning to France a few months later (Gérard 1918, 239-240). Judging the shipowner's final claim to be unreasonably high, the minister not only reduced the compensation to 200,000 taels but also ignored Marty's further capital claims, such as a request for extra promises or future guarantees. ${ }^{49}$ Accordingly, Consul Kahn, in his meeting with the two prefects in Hoihow on April 14, 1897, fixed the compensation at 200,000 taels, and the agreement was signed on June 4, 1897. When Gérard and the Chinese ministers approved and ratified the deal in Peking on July 10, 1897, the case was closed for French policy makers. ${ }^{50}$

Even so, Marty had merely won the battle and not the war, damaging in the long term his connections with Chinese business circles. His reputation as a businessman was severely harmed in the eyes of the Chinese, who regarded him as greedy, unreliable, and untrustworthy, something that had become evident in the Hoihow merchants' petition of October $1896 .{ }^{51}$ Therefore, French officials strongly advised Marty to restore trust as soon as possible and to avoid any future confrontation and animosity. ${ }^{52}$ 


\section{Germany's Diplomatic Nonintervention}

Marty's considerable monetary gain concerned Jebsen and Co. greatly with regard to the preparedness of Chinese merchants to continue shipping their cargo on the firm's vessels. Consequently, on July 6, 1897, Consul Dr. Ludwig von Loeper, being temporarily in charge of the German consulates both in Hong Kong and Canton, approached Viceroy Tan to issue a proclamation at Hoihow and Pakhoi, again stressing equal treatment for ships of all nations. ${ }^{53}$ Although Tan complied, his instructions were ignored by local officials. At Hoihow his order was completely disregarded, and at Pakhoi, on August 17, 1897, the proclamation's text contradicted German interests, stating: "When shipping goods everyone must be treated equal, and a certain ship should not be picked out for loading." Upon later reading the original Chinese version, Knappe found that it forbade shippers to select a specific vessel and therefore meant just the opposite of giving freedom to use any ship for transport. ${ }^{54}$

As a result of the ambiguous wording, Prefect Liu instructed Chinese merchants on pain of punishment not to give the larger part of their cargoes to Jebsen's ships. Furthermore, Chinese officials tried to recover from shippers a part of Marty's compensation. Under these threats Chinese firms in Pakhoi instructed their branches in Hong Kong not to give German vessels more cargo than French ones. Therefore, the three Jebsen coasters serving the line received less than half or no cargo at all from mid-August to early November $1897 .^{55}$

The new crisis led to reactions on several sides: first, Jebsen and Co., estimating its monthly losses to be at least 5,000 Mexican dollars, submitted on October 25, 1897, its first claim for damages to Consul Loeper, justifying this demand by declaring the actions of Chinese officials to be contrary to commercial liberty. Second, on October 26, 1897, a new proclamation was issued at Hoihow and Pakhoi clearly stating that shippers were free to use any ship for transporting cargo. Third, on the same day, Loeper appealed to Viceroy Tan, who accordingly gave orders so that the earlier announcement was followed up, on November 5 and 6, 1897, by two more proclamations reiterating the former's position.

However, Jebsen and Co., noting the ambiguous wording of the proclamation of August 17, 1897, submitted, on November 25, 1897, its second claim for damages to Consul Loeper, calculating losses of at least 15,000 Mexican dollars. When transferring the case to Minister von Heyking in Peking, Loeper supported the claim and suggested dispatching a ship of the German First Cruiser Division from Kiaochow to Hoihow and Pakhoi to boost pressure on the Chinese. ${ }^{56}$ 
For Heyking, such a forceful demonstration of military power in South China was out of the question due to current events in North China. On a personal visit to his French counterpart, Gérard, six months earlier, Heyking had revealed Germany's interest in acquiring a territorial base in China in the form of a naval station; he also announced that Germany would take care to stay outside of regions that France considered to be within her sphere of influence in China. With the widely unexpected occupation of Kiaochow Bay in the northeastern province of Shandong on November 14, 1897, by German naval troops, any further display of military aggression, especially in South China, was to be avoided, as Heyking noted, "because it would now unnecessarily annoy the French against us." ${ }^{, 57}$ The Foreign Office took the same stance, stating that "the current political conditions in East Asia are contrary to the realization of that idea.",58

At that time the German minister was involved in intensive negotiations with the Chinese government about leasing Kiaochow with the intention of developing it into a Germanadministered naval and trading hub in China (Schrecker 1971, 43-58; Mühlhahn 2000, 107110). The only show of support for Jebsen was given in the minister's letter of January 11, 1898, to the Tsungli Yamen, in which he stated: "The damage is only attributed to wrong and casual measures of the respective Chinese authorities which instead of keeping an eye on liberty of commerce imposed restrictions on it; and these were not immediately abolished even after they had been reminded of being contrary to the treaties." 59

However, because ongoing negotiations with the Chinese government regarding Kiaochow could not be hampered by any confrontation with France, the minister admitted on February 11, 1898, that, "despite my fervent wish to be helpful to German interests and especially to the shipping company which was particularly commended to me, I may not disregard that in order to avoid as much as possible a clash with French political claims in those ports, thus special caution is imperative in this matter." Therefore, a show of might for a rather irrelevant issue was out of the question. ${ }^{60}$ Although on Knappe's initiative more letters on the issue were exchanged between the German and Chinese authorities, the case was effectively closed for Chinese and German policy makers, with Jebsen and Co. receiving no monetary compensation for its losses. 


\section{Conclusion}

The case presented here highlights a historical moment during which political and economic rivalries among the treaty powers in China were so extreme as to merit multiple instances of interference into what might otherwise be considered the "private" realm of business. In the period of "new" imperialism in China and East Asia, France actively strived to create a sphere of influence in southwest China or in the wider Gulf of Tonkin region. In this context, the Haiphong-based Tonkin Shipping Company played an instrumental role in justifying French economic interests in the region. The firm's owner, A. R. Marty, knew how to carefully exploit such political aspirations for his profit-driven business interests. The intervention of French officials on behalf of Marty's company was the result of France's new expansionist policy in China after 1895, facilitated by harmonious relations between the two countries in the aftermath of the Sino-Japanese War.

Marty's desire for a shipping monopoly in the Gulf of Tonkin triggered strong reactions from his Chinese clients, especially the Pakhoi and Hoihow shippers. Establishing the Tsap Yet syndicate and boycotting Marty's vessels was the beginning of worsening business relations with the French shipowner, who, backed by strong political support of French officials in China, was able to win considerable financial compensation from the Chinese government. At the same time, his actions ruined his reputation as a businessman in the eyes of his main client base.

In their attempt to break Marty's monopoly and to regain free competition among shipping companies, the affected Chinese businessmen quickly learned that methods such as setting up a secret and then more formal syndicate and boycotting Marty's ships as economic weaponry against him proved unsuccessful in the face of combined political and military pressure from Chinese and French authorities. The best solution to escape such constraints appeared to be the establishment of a close business arrangement with another foreign firm. The Sino-German partnership of Yuen Cheong Lee and Co. and Jebsen and Co. was possible because of mutual trust between the owners after many years of doing business together. The business association secured reliable shipments for Chinese merchants and gave Jebsen and Co. the chance to defend its major share in the shipping market of the Gulf of Tonkin.

German diplomatic and consular personnel in China took a cautious stance with regard to the crisis in the shipping market in South China when Germany was about to create a sphere of interest in Northeast China. Fearing interference from other imperialist powers such as France, 
Germany retained only a token agreement in support of Jebsen's claim for damages. Even when Michael Jebsen, owner of the M. Jebsen Shipping Company and a member of the German National Parliament, intervened by contacting the German foreign minister, who accordingly instructed the German minister in Peking, political interests but also tacit acceptance of France's sphere of influence in southwest China prevented any considerable support for the German company.

All in all, this article, drawing from a variety of unpublished archival materials, contributes to the history of the shipping business in modern China. Western shipping companies employing modern steam coasters provided important transport services to Chinese merchants through the conveyance of bulk goods via coastal, riverine, and interregional shipping in East Asia. The high degree of Sino-Western cooperation in this area led to the joint capitalization of shipping companies and joint organization of services, with the result that, at the end of the nineteenth century, Chinese merchants had in hand impressively large capital in Western shipping companies.

In the context of rethinking business history in modern China, the case study presented here offers a more nuanced picture by highlighting two major themes:

First, the historical context - when imperialist rivalries in China reached a climax in terms of their effects on shipping business operations - needs to be taken into account. Chinese merchants showed themselves able to react efficiently concerning what they considered to be unfair business practices by a foreign firm. However, using the boycott as a political weapon was a strategy that proved successful only in the very short term, while close cooperation with another Western company was a better medium- and long-term strategy to escape political pressures from both the Chinese and foreign governments.

Second, mutual interest and long-established mutual trust between a Chinese and a German firm after many years of having done business together was without doubt the precondition to establishing close business cooperation. This was realized in the form of an agreement about joint organization of shipping services. That such a combination was regarded as unusual at the time is confirmed by hitherto unpublished archival evidence revealed in this case study. In this way, the case provides nuanced insights into the history of economic interaction between Chinese and foreign business in the late nineteenth century. 
Bert Becker is associate professor of History at the University of Hong Kong.

\section{Notes}

1 The only exceptions are journal articles by de Gantès $(2004,228)$ and Martinez (2007, 90 ), in which the shipping rivalry between Marty and Jebsen in the 1890s is very briefly discussed based on documents from ANOM (Aix-en-Provence); however, the precise background and business connections between the firms involved remained unknown to the authors.

2 There are a few newspaper articles on the 1895 boycott and its aftermath. See, for example, "Boycotting a French Steamer Line-Claim against the Chinese Government," Hong Kong Daily Press, February 1, 1896; "French Indo-China," The London and China Telegraph, July 19, 1897; and "South-West China," The London and China Telegraph, May 31, 1898.

3 The French leasehold colony of Kwang-chow-wan on the east coast of Leichow Peninsula, Kwangtung Province, was established by the temporary Sino-French agreement of April 10, 1898, whose core contents were substantiated and confirmed in the joint convention of November 16, 1898. For ninety-nine years, France leased from China the Bay of Kwang-chow-wan, including three islands of 842 square kilometers total, with the right to establish a naval station and a coal depot. In 1900, the colony became an administrative part of French Indochina; in 1946, it was returned to China (Montagnon 2010).

4 There is little documentation available on Marty or his firms; the earliest reference is in the special edition of the Haiphong-based newspaper Le Courrier d'Haiphong: Supplément 1886-1895 au Millième Numéro du Journal, December 24, 1895, 7-8. An article to celebrate the hundredth year of Marty's birth was published in Bulletin Trimestriel de la Société Amicale des Anciens Tonkinois (1940, 8-14). Brief overviews of the firms' commercial activities in Indochina and China, and also in the local context of Haiphong as the French colony's major northern port, are available in Raffi (1994, 182 183 ) and Villemagne (2008, 699-701). Information on Marty's rice shipping business, although with factual errors, is available in Martinez (2007).

5 "Contrat passé entre M. M. Marty et d'Abbadie et le Gouvernement Général pour le service des correspondances fluviales au Tonkin, 1886-1888" (Folder 6274, ANOM) and "Contrat du 16 septembre 1893 entre M. M. Marty et d'Abbadie et le Gouvernement Général pour le service des correspondance fluviales du Tonkin, et actes additionnels" (Folder 6275, ANOM).

6 Auguste Raphael Marty (Haiphong) to Governor-General Paul Beau (Hanoi), June 2, 1903 (Folder 6154, ANOM).

7 Note of the Administrative Service (Hanoi) to the Governor-General of Indochina, October 5, 1906 (Folder 3400, ANOM).

8 Le Courrier d'Haiphong: Supplément 1886-1895 au Millième Numéro du Journal, December 24, 1895, 8-9. This comment also shows that the assertion of Haiphong-based French shipping companies dominating "the trade on the Kwantung coast between Hong 
Kong and Haiphong, including the island of Hainan" by the mid-1890s (Lee 1989, 23) is not a reflection of the true situation.

9 The M. [Michael] Jebsen Shipping Company was founded in 1878 in Apenrade (Schleswig-Holstein, Germany) by Michael Jebsen (1835-1899; father of Jacob Jebsen). In 1885, its steamer fleet counted eight ships after all ships had been transferred to Hong Kong; in 1903-1904 the company reached its peak with seventeen ships, and in 1913 the company had eleven ships. Starting in March 1895, the principal agent of the M. Jebsen Shipping Company was Jebsen and Co. Ltd. in Hong Kong, owned by Jacob Jebsen (1870-1941) and his business associate, Heinrich Jessen (1865-1931). Operating in East Asia, the Jebsen steamers were frequently chartered by Chinese companies to transport all kinds of cargo in coastal and interregional shipping. Jebsen and Co. Ltd., having started in 1895 as a shipping agency and general trading company, soon occupied a leading position in the foreign trade of China and Hong Kong. The early years of the Jebsen firms are dealt with in Hänisch (1970, 25-41), Miller and Wasmuth (2008, 8-21), Becker (2010), and Becker (2012, 315-323, 576-578).

10 “E. L. B. Allen (Pakhoi) to Consul Dr. Wilhelm Knappe (Canton), January 24, 1896" (in English) (Folder 1169, Peking II, PA AA). "Memorandum of Wilhelm Knappe," Die französische Konkurrenz in Hoihow und Pakhoi, December 1896 (Folder 1170, Peking II, PA AA).

11 "Wilhelm Knappe (Canton) to Gustav Baron Schenck zu Schweinsberg (Peking), January 3, 1896" (Folder 1169, Peking II, PA AA) and "Memorandum of Wilhelm Knappe," Die französische Konkurrenz in Hoihow und Pakhoi, December 1896 (Folder 1170, Peking II, PA AA).

12 "Wilhelm Knappe (Canton) to Gustav Baron Schenck zu Schweinsberg (Peking), January 3, 1896," including Articles of the Chap Yik Steamship Company (in English) (Folder 1169, Peking II, PA AA).

13 “Auguste Gérard (Peking) to Augustin Juline Fourès (Hanoi), November 27, 1895" (Folder 19925, ANOM) and "Le Chinois au Tonkin" (L'Extrême-Orient, November 21, 1895).

14 "Auguste Raphael Marty (Haiphong) to Governor-General Paul Beau (Hanoi), June 2, 1903” (Folder 6154, ANOM).

15 The Treaty between France and China, dated June 27, 1858, was published in both French and Chinese. The French version is in Mayers ([1903] 1906, 59-70). The following translation into English of Article 14 is in The Directory and Chronicle for China, etc. for the Year 1917 (1917, 75): "No privileged commercial society shall henceforward be established in China, and the same shall apply to any organised coalition having for its end the exercise of a monopoly of trade. In case of the contravention of the present article the Chinese Authorities, on the representation of the Consul or Consular Agent, shall advise as to the means of dissolving such associations, of which they are also bound to prevent the existence by the preceding prohibitions, so as to remove all that may stand in the way of free competition."

16 "Auguste Gérard (Peking) to Augustin Juline Fourès (Hanoi), November 27, 1895 and December 23, 1895" (Folder 19925, ANOM).

17 The new rules of Tsap Yet's head firm in Hong Kong called The Rules of the Chak Yik Steam-Ship Company were put in print, with one copy enclosed in the "Report of Camille 
Gauthier (Pakhoi) to Foreign Minister Marcellin Berthelot (Paris), November 20, 1895" (Folder 235/1, AEAD).

18 "Wilhelm Knappe (Canton) to Gustav Baron Schenck zu Schweinsberg (Peking), January 3, 1896" (Folder 1169, PA AA).

19 "E. L. B. Allen to Wilhelm Knappe (Canton), January 24, 1896" (Folder 1169, PA AA).

20 "Memorandum of Wilhelm Knappe, Die französische Konkurrenz in Hoihow und Pakhoi, December 1896" (Folder 1170, PA AA).

21 “À Pakhoi," Le Courrier d'Haiphong, January 25, 1896, and "Boycotting a French Steamer Line - Claim against the Chinese Government," Hongkong Daily Press, February 1, 1896.

22 "E. L. B. Allen (Pakhoi) to Wilhelm Knappe (Canton), January 24, 1896" (Folder 1169, PA AA).

23 “À Pakhoi,” Le Courrier d'Haiphong, January 25, 1896.

24 "Wilhelm Knappe (Canton) to Gustav Baron Schenck zu Schweinsberg (Peking), February 2, 1896" (Folder 1169, PA AA).

25 "The Ministers of Tsungli Yamen (Peking) to Gustav Baron Schenck zu Schweinsberg (Peking), February 2, 1896" (Folder 1160, PA AA). See also Gérard (1918, 239).

26 "Wilhelm Knappe (Canton) to Gustav Baron Schenck zu Schweinsberg (Peking), February 2, 1896" (Folder 1169, PA AA).

27 "A. Schomburg \& Co. (Pakhoi) to Wilhelm Knappe (Canton), January 21, 1896" (Folder 1169, PA AA).

28 "Wilhelm Knappe (Canton) to Gustav Baron Schenck zu Schweinsberg (Peking), February 29, 1896," including undated attachments (Commitment of the Pakhoi Merchants and Proclamation of the Prefect [German translation from Chinese], Folder 1169, PA AA).

29 Jacob Jebsen, Mein Leben (1928), 31-32 (unpublished manuscript, JJHA).

30 "E. L. B. Allen (Pakhoi) to Wilhelm Knappe (Canton), January 24, 1896 (in English)" (Folder 1169, PA AA).

31 "Memorandum of Wilhelm Knappe" (Die französische Konkurrenz in Hoihow und Pakhoi, December 1896, Folder 1170, PA AA); "Wilhelm Knappe (Kanton) to Edmund Baron von Heyking (Peking), July 17, 1898” (Folder 1171, PA AA).

32 Jacob Jebsen, Mein Leben (1928), 31-32 (unpublished manuscript, JJHA); [Johann] Heinrich Jessen, Recollections and Observations written 1918, 24 (Folder PS 4920, JJHA); Hänisch (1970, 46).

33 "Memorandum of Wilhelm Knappe" (Die französische Konkurrenz in Hoihow und Pakhoi, December 1896, Folder 1170, PA AA).

34 [Johann] Heinrich Jessen, Recollections and Observations written 1918, 24 (Folder PS 4920, JJHA). The agreement (in English) is reprinted in Hänisch (1970, 46-47).

35 Jacob Jebsen (Hong Kong) to Heinrich Jessen (Hamburg), February 26, 1908 (Folder B10-01-017, JJHA).

36 Jacob Jebsen (Apenrade) to Heinrich Jessen (Hong Kong), October 15, 1900 (Folder A01-01-294, JJHA).

37 The Hoihow firm, initially a branch of Yuen Cheong Lee and Co. (1896-1902) and then of Jebsen and Co. (1902-1919), proved to be so lucrative that both sides benefited greatly and drew remarkable material gains from it. In 1901, Y. T. Chau also became comprador 
in Jebsen and Co. and remained in that position until the outbreak of the First World War (Hänisch [1970], 221-222, 456-458).

38 "Wilhelm Knappe (Canton) to Gustav Baron Schenck zu Schweinsberg (Peking), February 29, 1896" (Folder 1169, PA AA).

39 "Auguste Raphael Marty (Haiphong) to Governor-General Paul Beau (Hanoi), June 2, 1903" (Folder 6153, ANOM).

40 "Memorandum of Wilhelm Knappe" (Die französische Konkurrenz in Hoihow und Pakhoi, December 1896, Folder 1170, PA AA).

41 “Fasuo Jiyi gongsi peichang” 法索集益公司賠償 [French claim for compensation concerning the case of Tsap Yet Company] (No. 01-24-032-02-006, TYAAS).

42 “Fasuo Jiyi gongsi peichang“法索集益公司賠償 [French claim for compensation concerning the case of Tsap Yet Company] (No.01-24-032-02-007, TYAAS).

43 "Wilhelm Knappe (Canton) to Edmund Baron zu Heyking (Peking), October 15 and 27, 1896" (Folder 1169, PA AA).

44 "Edmund Baron von Heyking (Peking) to Wilhelm Knappe (Canton), November 16, 1896" (Folder 1169, PA AA).

45 "Wilhelm Knappe (Canton) to Gustav Baron Schenck zu Schweinsberg (Peking), April 25, 1896" (Folder 1169, PA AA) and "Wilhelm Knappe (Canton) to Gustav Baron Schenck zu Schweinsberg (Peking), December 7, 1896” (Folder 1170, PA AA).

46 "Wilhelm Knappe (Canton) to Edmund Baron zu Heyking (Peking), November 26, 1896" (Folder 1196, PA AA).

47 "Undated report of J. F. Schoenicke, December 1896" (Folder 1170, PA AA).

48 "Ludwig von Loeper (Hong Kong) to Edmund Baron von Heyking (Peking), July 16, 1897" (Folder 1170, PA AA).

49 "Edmund Baron von Heyking (Peking) to Ludwig von Loeper (Hong Kong), July 29, 1897" (Folder 1170, PA AA) and "Auguste Raphael Marty (Haiphong) to GovernorGeneral Paul Beau (Hanoi), June 2, 1903" (Folder 6153, ANOM).

50 “Colonial Minister André Lebon (Paris) to Paul Doumer, Governor-General of Indochina (Hanoi), September 11, 1897" (Folder 56222, ANOM).

51 Petition of Hoihow merchants including the reply to calumnious accusations against them, undated [October 1896] (Folder 1169, PA AA).

52 Such recommendation to Marty is reported in "Letter of Governor-General Paul Doumer (Hanoi) to Colonial Minister André Lebon (Paris), November 2, 1897” (Folder 56222, ANOM).

53 "Ludwig von Loeper (Hong Kong) to Edmund Baron von Heyking (Peking), July 2, 1897" and "Ludwig von Loeper (Hong Kong) to Governor-General Tan Chung-lin (Canton), July 6, 1897” (Folder 1170, PA AA).

54 "Wilhelm Knappe (Canton) to Edmund Baron von Heyking (Peking), June 27, 1898" (Folder 1171, PA AA).

55 "Jebsen and Co. (Hong Kong) to Consul Ludwig von Loeper (Hong Kong), November 25, 1897 (copy)" (Folder 1170, PA AA).

56 "Ludwig von Loeper (Hong Kong) to Edmund Baron von Heyking (Peking), November 4, 17, and 29, 1897" (Folder 1170, PA AA). 
57 "Ludwig von Loeper (Hong Kong) to Imperial Chancellor Chlodwig Prince zu Hohenlohe-Schillingsfürst (Berlin), November 29, 1897 (copy)" and "Edmund Baron von Heyking (Peking) to the Foreign Office (Berlin), December 26, 1897" (Folder 1170, PA AA).

58 "Oswald Baron von Richthofen, Undersecretary of State of the Foreign Office (Berlin), to Edmund Baron von Heyking (Peking), January 25, 1898” (Folder 1171, PA AA).

59 "Edmund Baron von Heyking (Peking) to the Tsungli Yamen (Peking), January 11, 1898" (Folder 1171, PA AA).

60 "Edmund Baron von Heyking (Peking) to Wilhelm Knappe (Canton), February 11, 1898" (Folder 1171, PA AA).

\section{References}

Archival sources

Affaires Étrangères Archives Diplomatiques, Paris (AEAD)

Pakhoi, 1888-1895, Correspondance consulaire et commerciale, 1793-1901

Archives Nationales d'Outre-mer, Aix-en-Provence (ANOM)

Gouvernement-Général de l'Indochine

Jebsen and Jessen Historical Archives, Aabenraa (JJHA)

Politisches Archiv des Auswärtigen Amts, Berlin (PA AA) Peking II

Tsungli Yamen Archives, Institute of Modern History, Academia Sinica, Taipei (TYAAS)

Fasuo Jiyi gongsi peichang 法索集益公司賠償 [French claim for compensation concerning the case of Tsap Yet Company], No. 01-24-032-02-006.

Fasuo Jiyi gongsi peichang 法索集益公司賠償 [French claim for compensation concerning the case of Tsap Yet Company], No. 01-24-032-02-007.

$\underline{\text { Secondary sources }}$

Aldrich, Robert, and Kirsten McKenzie. 2014. "Why Colonialism?” In The Routledge History of Western Empires, edited by Robert Aldrich and Kirsten McKenzie, 3-13. London: Routledge.

Allen, George Cyril, and Audrey G. Donnithorne. 1954. Western Enterprise in Far Eastern Economic Development: China and Japan. London: George Allen and Unwin.

Armstrong, John. 2009. The Vital Spark: The British Coastal Trade, 1700-1930. St. John's, Newfoundland: IMEHA.

Armstrong, John, and Andreas Kunz, eds. 2002. Coastal Shipping and the European Economy, 1750-1980. Mainz: von Zabern.

Bach, Mette Haugaard. 2014. "Randersskibe på Kinakysten” [Randers ships at the China coast]. In Arbog 2014 [Yearbook 2014], edited by Museum Østjylland [Museum of Eastern Jutland, Denmark], 53-63. Randers: Narayana.

Barney, Jay B., and Mark H. Hansen. 1994. "Trustworthiness as a Source of Competitive Advantage." Strategic Management Journal 15: 175-190.

Becker, Bert. 2010. "Coastal Shipping in East Asia in the Late Nineteenth Century." Journal of the Royal Asiatic Society Hong Kong Branch 50: 245-302. 
. 2012. Michael Jebsen: Reeder und Politiker, 1835-1899: Eine Biographie [Michael Jebsen: Shipowner and politician, 1835-1899: A biography]. Kiel: Ludwig.

Bensacq-Tixier, Nicole. 2008. Histoire des diplomates et consuls français en Chine (1840-1911) [History of French diplomats and consuls in China (1840-1911]. Paris: Les Indes Savantes.

Brötel, Dieter. 1996. Frankreich im Fernen Osten: Imperialistische Expansion in Siam und Malaya, Laos, und China, 1880-1904 [France in the Far East: Imperialist expansion in Siam and Malaya, Laos, and China, 1880-1904]. Stuttgart: Steiner.

Bulletin Trimestriel de la Société Amicale des Anciens Tonkinois [Quarterly bulletin of the Association of Former Tonkinese], no. 9. 1940. Hanoi: G. Taupin.

Cady, John F. 1967. The Roots of French Imperialism in Eastern Asia. Ithaca, NY: Cornell University Press.

Carroll, John M. 2005. Edge of Empires: Chinese Elites and British Colonials in Hong Kong. Cambridge, MA: Harvard University Press.

Chen Zhanqi 陳湛綺, ed. 2008a. Wanqing waijiao huiwu bing waiwu miqi dangan huibian 晚清外交會晤并外務密啟檔案匯編, 第五冊 [Collected archival documents recording the meetings between the late Qing government and foreign diplomats, and from the secret archival documents of the Chinese Foreign Ministry, volume 5]. Beijing: China National Microfilming Center for Library Resources.

, ed. 2008b. Wanqing waijiao huiwu bing waiwu miqi dangan huibian 晚清外交會晤并外務密啟檔案匯編, 第六冊 [Collected archival documents recording the meetings between the late Qing government and foreign diplomats, and from the secret archival documents of the Chinese Foreign Ministry, volume 6]. Beijing: China National Microfilming Center for Library Resources.

De Gantès, Gilles. 2004. "Power and Weakness: French Presence in Southern China Sea (18401910)."Asia-Pacific Forum 26: 209-240.The Directory and Chronicle for China, etc. for the Year 1917. 1917. Hong Kong: The Hongkong Daily Press.

Doubleday, Page and Company, ed. 1903. The World's Work 6 (5). New York: Doubleday, Page and Company.

Faure, David. 2006. China and Capitalism: A History of Business Enterprise in Modern China. Hong Kong: Hong Kong University Press.

Gérard, Auguste. 1918. Ma Mission en Chine (1893-1897) [My mission in China (1893-1897)]. Paris: Plon.

—. 1928. Mémoires d'Auguste Gérard [Memoirs of Auguste Gérard]. Paris: Plon.

Gipouloux, François. 2009. La méditerranée asiatique: Villes portuaires et réseaux marchands en Chine, au Japon et en Asie du Sud-est, XVIe-XXIe siècle [The Asian Mediterranean: Port cities and mercantile networks in China, Japan, and Southeast Asia, 16th-20th centuries]. Paris: CNRS.

Gu Yurui 顧裕瑞 and Li Zhijian 李志儉, eds. 1988. Beihai gangshi 北海港史 [A history of the port of Pakhoi]. Beijing: Renmin jiaotong chubanshe [People's transportation publishing house].

Hänisch, Adolf von. 1970. Jebsen and Co. Hongkong: China-Handel im Wechsel der Zeiten 1895-1945 [Jebsen and Co. Hong Kong: China trade in changing times 1895-1945]. Apenrade: Private Print. 
Harlaftis, Gelina, and John Theotakas. 2002. "Maritime Business during the $20^{\text {th }}$ Century: Continuity and Change." In The Handbook of Maritime Economics and Business, edited by Costas Th. Grammenos, 9-34. London: Lloyd's of London Press.

The Hundred and Twentieth Report of the London Missionary Society. 1915. London: The London Missionary Society.

Hsü, Immanuel C. Y. 2000. The Rise of Modern China. 6th ed. Oxford: Oxford University Press.

Lee, Robert. 1989. France and the Exploitation of China 1885-1901: A Study in Economic Imperialism. Hong Kong: Oxford University Press.

Liu, Kwang Ching. 1956. Anglo-American Steamship Rivalry in China, 1862-1874. Cambridge, MA: Harvard University Press. . 1964. "British-Chinese Steamship Rivalry in China, 1873-85." In The Economic Development of China and Japan, edited by C. D. Cowan, 49-77. New York: Praeger.

Martinez, Julia. 2007. "Chinese Rice Trade and Shipping from the Vietnamese Port of Hai Phong." Chinese Southern Diaspora Studies 1: 82-96.

Mayers, William Frederick, ed. (1903) 1906. Treaties between the Empire of China and Foreign Powers. 5th ed. Shanghai: North China Herald.

Meyer, David R. 2000. Hong Kong as a Global Metropolis. Cambridge: Cambridge University Press.

Miller, Laura, and Arne Cornelius Wasmuth. 2008. Three Mackerels: The Story of the Jebsen and Jessen Family Enterprise. Hong Kong: Hongkongnow.com Ltd.

Miller, Michael B. 2012. Europe and the Maritime World: A Twentieth-Century History. Cambridge: Cambridge University Press.

Montagnon, Pierre, 2010. "Kouang-Tcheou-Wan" [Kwang-chow-wan]. In Dictionnaire de la colonisation française [Dictionary of French colonization], edited by Pierre Montagnon, 412. Paris: Pygmalion.

Morse, Hosea Ballou. 1909. The Guilds of China. London: Longmans, Green.

Mühlhahn, Klaus. 2000. Herrschaft und Widerstand in der "Musterkolonie Kiautschou": Interaktionen zwischen China und Deutschland, 1897-1914 [Power and resistance in the "model colony" of Kiaochow: Interactions between China and Germany, 1897-1914]. Munich: Oldenbourg

Osterhammel, Jürgen. 1989. China und die Weltgesellschaft: Vom 18. Jahrhundert bis in unsere Zeit [China and global society from the eighteenth century until the present]. Munich: Beck.

Otte, Friedrich. 1930. "Shipping in China and Chinese Shipping Abroad." In Chinese Economic Journal 6 (2): 123-152.

Raffi, Gilles. 1994. Haiphong: Origines, conditions et modalités du développement jusqu'en 1921 [Haiphong: Origins, conditions, and methods of development until 1921]. Aix-enProvence: Université de Provence.

Remer, C. F. 1966. A Study of Chinese Boycotts: With Special Reference to their Economic Effectiveness. Taipei: Cheng-Wen.

Sabel, C. F. 1993. "Studied Trust: Building New Forms of Cooperation in a Volatile Economy." Human Relations 46 (9): 1133-1170.

Schrecker, John E. 1971. Imperialism and Chinese Nationalism: Germany in Shantung. Cambridge, MA: Harvard University Press.

Stuart, Graham H. 1921. French Foreign Policy from Fashoda to Sarajevo (1898-1914). New York: The Century. 
Sun Xuelei 孫學雷 and Liu Jiaping 劉家平. 2003. Guojia tushuguan cang Qingdai guben waijiao dangan 國家圖書館藏清代孤本外交檔案, 第二十七冊 [The sole edition of the Qing dynasty's diplomatic documents in the collection of the National Library of China, vol. 27]. Beijing: China National Microfilming Center for Library Resources.

Sze, Tsung-Yu. (1925) 1971. China and the Most-favored-nation Clause. New York: Fleming H. Revell (reprint, Taipei: Ch'eng Wen).

Tixier, Nicole. 2008. "La Chine dans la stratégie impériale: Le rôle du Quai d'Orsay et de ses agents [China in the imperialist strategy: The role of the Quai d'Orsay and its officials]. In L'esprit économique impérial (1830-1970): Groupes de pression \& réseaux du patronat colonial en France \& dans l'empire [The Imperial economic mind (18301970): Pressure groups and networks of colonial managers in France and in the Empire], edited by Hubert Bonin, Catherine Hodeir, and Jean-François Klein, 65-84. Paris: Publications de la SFHOM.

Tsai, Jung-fang. 1993. Hong Kong in Chinese History: Community and Social Unrest in the British Colony, 1842-1913. New York: Columbia University Press.

Villemagne, Claire. 2008. "Les Chambres de commerce du Tonkin, 1884-1894: Sociabilité culturelle ou mission économique?" [The chambers of commerce of Tonkin, 1884-1894: Cultural sociability or economic mission?]. In L'esprit économique impérial (18301970): Groupes de pression \& réseaux du patronat colonial en France \& dans l'empire [The Imperial economic mind (1830-1970): Pressure groups and networks of colonial managers in France and in the empire], edited by Hubert Bonin, Catherine Hodeir, and Jean-François Klein, 697-714. Paris: Publications de la SFHOM.

Wong, Sin Kiong. 2002. China's Anti-American Boycott Movement in 1905: A Study in Urban Protests. New York: Peter Lang.

Wray, William D. 1984. Mitsubishi and the N.Y.K., 1870-1914: Business Strategy in the Japanese Shipping Industry. Cambridge, MA: Harvard University Press. 